\title{
The Gametophytes and Embryo of the Cupressineae with special reference to Libocedrus decurrens.
}

BY

\author{
ANSTRUTHER A. LAWSON, Ph.D. \\ Assistant Professor of Botany in Stanford University, California, U.S.A.
}

With Plates XXIV-XXVI.

INTRODUCTION.

THE series of studies on the Gymnosperms which the writer has 1 published during the last three years, and of which the present memoir is the fourth, was undertaken with the idea that a detailed knowledge of the vestigial structures associated with the gametophyte generation might throw some light on the phylogenetic relationships of the various sub-groups of the Coniferales, and that the data, accumulated from the facts concerning such structures, might eventually be of some service in contributing to our knowledge as to the origin of the Gymnosperms in general. Although the Coniferales are second only to the Angiosperms as a dominating race of seed-plants, they are, nevertheless, a very ancient group, extending, as the fossil evidence would seem to indicate, as far back as the carboniferous period. In attempting to construct a phylogeny of a group of plants of such great antiquity from a study of recent forms, one must naturally rely almost entirely upon a study of those structures, the nature of which will throw light upon ancestral affinities. For instance, the prothallial cells in the microspore, the structures in the pollen-tube, the organization and form of the sperm cells, the megaspores, the tapetum, the megaspore membrane, the formation of the female prothallium, the structure of the archegonia, the ventral canal cell, the process of fertilization, and the development of the embryo, all show phases of phylogenetic interest. With the exception of the early history of the male gametophyte, all of these more or less vestigial structures are buried within the tissues of the sporophyte, and therefore are less liable to be modified and specialized by external factors, and more likely to preserve characters which are obviously primitive than those of the sporophyte. That the sporophyte contributes evidence of great value is clearly indicated by Professor Jeffrey's

Annals of Botany, Vo1. XXI. No. LXXXII. April, 1907.] 
('03, '05) investigations on the anatomy of the vascular system. Indeed, in any scheme which may be advanced concerning the phylogeny of this ancient group, the sporophyte as well as the gametophytes must constitute an essential part, for it is mainly from the point of view of anatomy that we can hope to correlate the evidence from the fossils-the structures associated with the sexual generation being so much more perishable.

In this series of studies no attempt has been made to follow any natural sequence in the types selected. It was thought that good results might be obtained by working up the available material first; leaving the more inaccessible and perhaps more interesting types, such as Arancaria and Agathis, for future investigations. The present paper is merely intended as an addition to the knowledge which we have already received from the works of Strasburger ('79), Arnoldi ('01), Land ('02), Coker ('03), and the present writer ('04) on the gametophytes of the Cupressineae. Special attention has been given to Libocedrus, because, up to the present, no observations have been recorded concerning the sexual generation of this genus. The work was commenced in the Laboratory of Stanford University, California, but most of it was carried on in the Jodrell Laboratory, Kew Gardens. To Lieut.-Col. Prain, C.I.E., F.R.S., Director of the Royal Gardens, Kew, and to Dr. D. H. Scott I wish to express my sincere thanks for extending to me the privileges of the Laboratory. My thanks are also due to Mr. L. A. Boodle, F.L.S., whose constant attention and many kindnesses aided materially towards the completion of the work.

\section{MATERIAL AND METHOdS.}

The collection of material for this investigation was commenced in March, 1903, and was continued at short intervals as time permitted. The collections extended over a period of two years. All of the material was obtained from trees growing in the arboretum of Stanford University. The Cupressineae are here richly represented in both genera and species, and the climatic conditions seem very favourable for the development and maturing of the fruit. Every year there is an abundance of cones on most of the trees.

The methods used are the same as those which I adopted in previous investigations on the Conifers (Lawson '04), and gave satisfactory results.

\section{The Male Gametophyte.}

In Libocedrus decurrens pollination takes place during the last week in March and early in April ; the period extending from two to three weeks. The first collections of the microsporangia were taken early in March, and at this time the pollen seemed fully developed-each grain having a thick exine and containing two nuclei, the latter being separated from each other by a distinct membrane. In the division of the spore before its 
discharge from the microsporangium, Libocedrus agrees with the majority of other Cupressineae, but apparently differs from Funiperus and Cupressus, where, according to Strasburger ('92) and Coker ('04), there is no division of the microspore nucleus until some time after pollination.

During the period of pollination the micropyle exudes a small globule of transparent liquid. The purpose of this is no doubt to catch the pollen more effectively, for an examination of the globule upon a slide under the microscope showed it to contain several pollen-grains. The same thing has been observed in other Conifers-especially in Taxus baccata, where the globule of liquid is particularly obvious. It was observed more frequently during the early morning, before the heat of the day had time to cause evaporation.

The pollen-grain of Libocedrus is-like that of other Cupressineae-very small. It contains but two cells, and in this regard resembles all other Conifers except the Abietineae and Podocarpeae. No trace of the survival of sterile prothallial cells was found. The single or first division which takes place, and which results in the organization of the generative and tube-nuclei, is the only division in the male gametophyte preceding that resulting in the formation of the body and stalk-nuclei. In view of more recent studies on the pollen, Coker's statement, that 'In the absence of any sterile prothallial cells, Taxodium agrees with the Cupressineae and Taxus, and differs from all other Conifers and Cycads,' is misleading ; for we now know that these prothallial cells are not of general occurrence among the Coniferales, but are probably confined to the Abietineae and Podocarpeae At the time of the shedding of the pollen in Libocedrus, the tube-nucleus is centrally situated, and is considerably larger than the generative nucleus. The latter was invariably found lying to one side near the spore-wall.

Several spores find their way to the apex of the nucellus, and here retain their positions for three or four weeks without any further visible changes. Meantime the cells lining the upper part of the integument grow inwards, and gradually close the micropyle in essentially the same manner as they do in Sequoia and Cryptomeria (Lawson, '04). The next indication of the further germination of the spore was its enlargement to about twice or three times its original size, and the appearance of the pollen-tube. The latter at first pushes out over the top of the nucellus, but very soon begins its downward penetration into the nucellar tissue, without any indication whatever of branching. Very young pollen-tubes were observed early in May, which was just about a month after pollination. There are usually three or four pollen-tubes present, but as many as six have been observed penetrating the tissue of a single nucellus. The courses they follow diverge very little out of the straight lines between the original points of penetration and the archegonial chamber below. Their growth is accompanied by the usual breaking down and disorganization of the nucellar tissue through 
which they pass. All of the tubes penetrate the tissue near the apex of the nucellus. In no case was I able to find any of the tubes growing down between the nucellus and the integument, as so commonly occurs in Sequoia sempervirens (Lawson, '04).

Just previous to the penetration of the pollen-tube into the nucellar tissue, the generative nucleus enlarges and prepares for division. That this division occurs when the pollen-tube is very young was shown by the fact that in material collected during the second week in May, when the tube had penetrated but a very short distance into the nucellus, the body-cell and stalk-nucleus were completely organized. The body-nucleus was easily distinguished from the stalk-nucleus because of its greater size, and also because it very soon becomes surrounded by a cell membrane. The young tube at this time thus contains the large body-cell and the stalk- and tubenuclei-the latter lying freely in the tube-cytoplasm. The body-cell is at first distinctly oval in form, and its long axis lies parallel to the long axis of the tube. Its nucleus is quite three or four times the size of the tube or stalk-nuclei. The latter structures are almost equal in size, and it is only from their position that they may be distinguished from one another; they are, however, always found in advance of the body-cell. The appearance of the body-cell, from material killed May $3 \mathrm{I}$, is shown in Pl. XXIV, Fig. 6. It will be seen that the cell is not so much oval in form as in earlier stages, and that its cytoplasm is very granular-containing more starch and other food substances than the tube-cytoplasm.

By June I the tube has completely penetrated the nucellus. Meantime the female prothallium has been developing rapidly, and the archegonia are fully organized and nearly ready for fertilization by the time the tip of the tube reaches the archegonial chamber. During its entire growth the contents of the tube are always found at the tip. Just about the time the archegonial chamber has been reached the body-cell divides, and as a result of this division two distinct male cells of equal size are formed. Fig. 6 represents the body-cell preparing for division. Fig. 7 represents the two male cells very soon after they have been formed. Fig. 6 was drawn from material killed May 31, and Fig. 7 June I. As may be seen from Fig. 7, the two male cells are not quite spherical in form, but each of them becomes spherical as soon as they separate from each other and before the archegonia have been reached. It will also be observed that the nucleus of each male cell is very large, with a single conspicuous nucleolus, and the chromatin, in the form of small, uniform granules, suspended on a network of linin.

The organization of two male cells of equal size seems to be a constant character of the Cupressineae (and I consider Taxodium and Cryptomeria as members of this group). The only exception which has so far been recorded is that of Cupressus Goweniana, in which Juel ('04) describes the 
Cupressineae, with special reforence to Libocedrus decurrens. 285

body-cell as giving rise to a complex of cells. Realizing the importance of such a condition, I have made a careful study of the pollen-tube in two other species of Cupressus, and the conditions found there were almost identical with those described above for Libocedrus. In both species studied I found that two male cells of equal size were organized, and that the stalkand tube-nuclei in addition to these constituted the entire nuclear structures of the pollen-tube. The two male cells were also followed through the fertilization stages. I am therefore compelled to regard the condition described by Juel in Cupressus Goweniana as simply an interesting abnormality. In addition to the two species of Cupressus which I have examined, the normal condition of two male cells of equal size occurs in Taxodium, Cryptomeria, Funiperus, Thuja, and Chamaecyparis. The only other Conifer outside of the Cupressineae in which two distinct equal male cells have been observed is Sequoia (Shaw, '96; Lawson, '04). In all other Conifers of which we have record the male cells are either unequal in size (Taxus, Belajeff, '93; Podocarpus, Coker, '02 ; Torreya taxifolia, Coulter and Land, '05), or they are represented only by nuclei as in the Abietineae (Dixon ('94), Blackman ('98), Coulter and Chamberlain ('01), Ferguson ('01)) and in Cephalotaxus (Lawson, '07).

As shown in Fig. 7, the male cells become packed with starch grains, and in this respect resemble other members of the Cupressineae. As soon as the male cells are formed the contents of the pollen-tube are discharged into the archegonial chamber. The pollen-tube itself apparently does not carry the male cells into the archegonium, as it does in the Abietineae and some other Conifers, but its function evidently ceases when the archegonial chamber has been reached and its contents discharged. As I shall point out later, the archegonia throughout the Cupressineae are arranged in a single group with a common layer of jacket-cells, and with their necks opening into a common cavity or chamber. It is into this common chamber that the contents of the various pollen-tubes are discharged. As the archegonia are numerous, their arrangement in a single group makes it possible and easy for each male cell to function, so that the contents of each pollentube may accomplish the fertilization of two separate archegonia. These conditions seem to offer a fair explanation why one of the male cells is not dwarfed and functionless as it is in many other Coniferales.

The history of the male gametophyte of Libocedrus resembles that of Thuja probably more closely than any other of the Cupressineae. It agrees in all essential points with the account given by Land ('02) of Thuja occidentalis, and also with my own observations on Thuja orientalis. The mature pollen of the latter species has but two nuclei-the generative and tube. The pollen-tubes develop and penetrate the nucellar tissue in identically the same fashion as they do in Libocedrus. P1. XXIV, Fig. I shows a young pollen-tube, and Fig. 2 shows at least four of them at a later stage. 
Fig. 3 represents a young pollen-tube more highly magnified, indicating the appearance and position of the body-cell and tube-nucleus. As shown in Fig. 4, the older body-cell of Thija orientalis differs slightly from that of Libocedrus in having a greater quantity of starch and food granules in its cytoplasm. Fig. 5 represents a mature male cell just previous to its entrance into an archegonium.

From Land's ('02) account of Thuja, Coker's ('04) account of Taxodium, and my own observations on Cryptomeria ('04), Libocedrus, Thija, Cupressus, and Chamaecyparis, there seems to be a striking uniformity throughout the Cupressineae in regard to the history of the male gametophyte. Such a close similarity in the microspores and pollen-tube structures apparently does not prevail between the members of any other group of the Coniferales.

\section{The Female Gametophyte.}

The first collections of material for the study of the megaspores in Libocedrus were taken early in March, but it was found that the megaspore mother-cells do not become differentiated until just about the time of pollination. Pl. XXIV, Fig. 8 represents a section of an ovule taken March 23 . At this time the integument extends for a considerable distance beyond the apex of the nucellus, and the micropyle is open. The nucellus itself is quite large and flat on the top. The megaspore mother-cells make their appearance in the middle region of the nucellus in a position in line with the point of insertion of the base of the integument, as indicated in Fig. 8. Two mother-cells are generally developed; occasionally but one was found. They very soon become differentiated from the surrounding tissue by their conspicuously large nuclei and their densely granular cytoplasm. Before dividing they become three or four times the size of the neighbouring cells. Fig. 9 represents two mother-cells lying side by side just before the first division. The spindle stages of this division were not found, so that I am unable to give an account of the chromatin at this critical time. Numerous preparations showed the megaspores after division, and from a study of these there is no doubt that each mother-cell dividing twice gives rise to four megaspores. Fig. Io shows four of the cells after the first division, and Fig. I I represents a section through eight spores soon after the second division. The spores are arranged in two rows-four in each row-and have the appearance of those found in Cryptomeria rather than the arrangement figured by Coker ('04) for Taxodium. In Taxodium, however, there is but a single mother-cell organized, while in Cryptomeria there are three or four. At the stage shown in Fig. I I all of the megaspores in Libocedrus look alike, and it is quite impossible at this time to say which one will develop into the prothallium. Surrounding the spores there is a single layer of loose cells, which may represent a tapetum. If such, it is a very poorly developed one, and by no means resembles that in Taxodium 


\section{Cupressineae, with special reference to Libocedrus decurrens. 287}

(Coker, '04) or in the Abietineae. All trace of this layer of cells becomes lost soon after the germination of the functional megaspore.

It seems that only one of the megaspores germinates; the others, along with the layer of loose cells, are presumably absorbed by the growing young prothallium. The functional spore at first increases enormously in size, and its growth is accompanied by a rapid and successive free nuclear division. Pl. XXV, Fig. I 2 shows the condition of the spore three weeks after the stage represented in PI. XXIV, Fig. II. The megaspore as shown in Fig. I 2 contains several large vacuoles separated from each other by irregular strands of cytoplasm, and in the cytoplasm are numerous free nuclei in various stages of mitosis. At this stage a very distinct but very thin megaspore membrane was observed. With the further increase in the size of the megaspore or young prothallium the vacuoles within it also increase and eventually flow together. From a study of these early stages in Libocedrus and many other Conifers it would seem that the large central vacuole, which is always present, performs a most important function in the growth of the young prothallium. The megaspore being confined within the sporangium, the young prothallium finds itself completely surrounded by nucellar tissue. Therefore, in order to rapidly produce prothallial tissue, it must not only increase greatly in size, but a rapid and plentiful supply of food material is necessary. Both of these objects must be accomplished by a pressure from within. The vacuole always keeps the parietal layer of cytoplasm at the periphery of the spore in close touch with the surrounding cells of the nucellus, and owing to the osmotic pressure which such conditions must necessarily bring about, the food substances from the surrounding tissue may be readily absorbed.

The manner in which the nucellar tissue of the prothallium becomes organized is not unlike that found in many other Conifers. By the first week in May the central vacuole has reached an enormous size, but as yet there is no trace of cellular tissue having been formed. Fig. I3 represents a section of the lower half of the prothallium at this time. Here the thin parietal layer of cytoplasm may be seen lining the spore membrane, and in it numerous free nuclei lie embedded at more or less regular intervals. The great size of the vacuole may be readily seen by comparing it with the size of the nuclei. The parietal layer of cytoplasm is a mere film; as shown in Fig. I4 it is quite as thin as the diameter of the nucleus. Very soon after the stage represented in Fig. I 3 the parietal layer increases to twice or three times its original thickness, and meantime free nuclear division has progressed and the nuclei lie much closer together. The last mitosis of the free nuclei results in the formation of cell-walls. These walls, however, only separate the nuclei from one another, the resulting primary cells being exposed on the inner side to the sap of the vacuole in the manner first described by Sokolowa ('90) for other Conifers. By their growth inward these primary 
prothallial cells ('alveoli') gradually encroach upon the space occupied by the vacuole, and as nuclear division continues numerous cross-walls are formed. The majority of the nuclei, however, are found on the inner exposed side of the primary cells, and seem to completely surround the diminishing vacuole in the manner shown in Fig. I5. It will be seen that the formation of the prothallial tissue in Libocedrus is essentially the same as that described by Coker ('04) for Taxodium. In Taxodium, however, Coker finds that cell-formation usually begins in the archegonial region earlier than it does in the basal region of the prothallium. This is not the case in Libocedrus, for the upper and basal regions develop permanent tissue about the same time. The central region seemed to be the last to develop cell-walls. In several cases traces of the diminishing central vacuole were observed, even after the archegonia had been organized.

In his investigation of the gametophytes of Thuja occidentalis, Land ('02) did not study the development of the megaspores or the formation of the endosperm. Coker ('04), however, has given a brief account of the development of the megaspores in Thija orientalis. My own observations of the megaspores of this latter species of Thuja do not agree entirely with those of Coker, although they do in the main. Coker finds that the single mother-cell becomes evident among the conspicuous spongy tissue, with its long axis often at right angles to the longitudinal axis of the ovule. This single mother-cell gives rise to four spores, which are arranged in the form of a tetrad. They are never arranged in a straight row, but are packed close together in such a way that only two or three nuclei may be seen in one section. I was unable to confirm these observations from my own preparations. In the first place I find that the tapetum, especially in the mother-cell stage, is not very conspicuous. I also find that there are generally two spore-mother-cells developed. Coker, however, states that occasionally two, or even three, may be differentiated. Many of my preparations show eight megaspores arranged in a single group, and they resemble very closely those which $\mathrm{I}$ have figured and described above for Libocedrus.

In regard to the development of the prothallium in Thuja, as yet no observations have been recorded. I have therefore carefully followed out the formation of the endosperm in T.orientalis, and record my observations here along with Libocedrus because these two genera seem to be very closely related. Only one megaspore germinates, and this is accompanied by the usual rapid free nuclear division and the subsequent development of the large central vacuole, with a thin parietal layer of cytoplasm at the periphery. The formation of the parietal endosperm tissue takes place in identically the same manner as described above for Libocedrus. Fig. 15 represents a section of the lower half of a young prothallium with the primary prothallial cells very much elongated, and by their growth gradually 
Cupressineae, with special reference to Libocedrus decurrens. 289

diminishing the central vacuole. The nuclei, during this growth of the primary cells, take up their characteristic position, on the inner side exposed to the vacuole. The final formation of permanent tissue takes place in the manner described above for Libocedrus and Taxodium (Coker, '04).

In Libocedrus, Thuja, Cupressus, and Chamaecyparis there is a distinct but poorly developed megaspore membrane at the time the archegonia are formed. An accurate account of the distribution and character of this membrane has already been given by Thomson ('05).

During the development of the central cells the sterile tissue at the apex of the prothallium grows forward, leaving the archegonia behind. The result of this forward growth is the formation of a large, deep, cup-like depression, or archegonial chamber, at the base of which the neck-cells of all the archegonia are closely clustered together. It is into this chamber that the contents of the various pollen-tubes are eventually discharged. While the male cells of the Cupressineae present characters which are apparently more primitive than those of the Abietineae, it must be remembered that their function and form are correlated with this highly specialized condition of the grouping of the archegonia. The formation of a common archegonial chamber into which the tube contents are discharged makes it possible for both male cells to function, and these structures are therefore not reduced or dwarfed as is the case with so many other Coniferales. This, however, will be discussed more at length under the head of fertilization.

\section{The Archegonia.}

The archegonia in Libocedrus are always arranged in a single group, and vary in number from ten to fifteen. The initials become differentiated as a group of cells at the apex of the prothallium as soon as the permanent tissue of the latter has been organized. They are all of superficial origin. The youngest initials observed were several times larger than the neighbouring cells, and their nuclei were very conspicuous and stained deeply. The further growth of the archegonia is evidently very rapid. The next stages observed showed the neck-cells, and these seemed to vary in number from four to six, arranged in a single tier, no periclinal walls being formed.

As soon as the neck-cells have been formed the central cell becomes elongated enormously, and the nucleus, which also increases in size, takes up a position in the cytoplasm very near the neck. Meantime quite a large $v$ acuole makes its appearance in the central region of the archegonium. The central nucleus now undergoes division, and this results in the organization of the egg-nucleus and the ventral canal-nucleus. All of the central nuclei of a single archegonial complex seem to divide nearly simultaneously. One preparation showed the nuclei of five neighbouring central cells in the spindle stage. Other preparations showed these nuclei in various stages of mitosis. All of the Cupressineae so far investigated, including Taxodium (Coker, '04) 
and Cryptomeria (Lawson,'04), fail to develop a membrane between the egg and ventral canal-nuclei. A similar condition is also found in Sequoia (Lawson, '04), Podocarpus (Coker, '02), Cephalotaxus (Lawson,'07), and probably also Torreya (Robertson, '04). In fact, it is only in members of the Abietineae that a ventral canal-cell has been found. In all other Conifers this primitive vestigial structure seems to be represented only by a nucleus. It has been a matter of considerable difficulty to determine which type of archegonium among the Coniferales is the most primitive, and this has given rise to much speculation. But now that so many forms have been investigated, it seems to me that the type of the Cupressineae, and all others where the ventral canal-cell is represented only by a nucleus, ought to be regarded as less primitive than that where a definite ventral canal-cell is formed, which seems to be characteristic of the Abietineae. This is merely emphasizing a point of phylogenetic importance which I recently suggested in the case of Cephalotaxus (Lawson, '07), and which has impressed itself more strongly upon me by a study of Libocedrus, Thuja, Cupressus, Chamaecyparis, and Funiperus.

In all of these types the size, shape, internal structure, and the method of grouping of the archegonia are very much alike. They all very much resemble Thuja occidentalis, first described by Land ('02). There are one or two points, however, in Land's description which I was unable to confirm. $\mathrm{He}$ states that almost immediately after the last anticlinal wall is formed the neck-cells begin to disorganize, and they are soon almost entirely assimilated by the central cells, which at this time are increasing in volume at a very rapid rate. My own observations convince me that the neck-cells in all of the Cupressineae which I have examined remain intact until just about the time of fertilization. Fig. 6 represents a section through an archegonial complex at the time the ventral canal-nucleus is being organized. It will be observed that the neck-cells are undisturbed. In regard to the number of archegonia, Land states that in Thija occidentalis the complex usually contains but six. Fig. 18 represents a cross-section of the group of archegonia in Thaja orientalis showing the presence of twentythree. Several preparations showed as many as twenty-four. In none of the Cupressineae which I have examined have I found as few as six archegonia in a single complex. In all other particulars the archegonia of this latter species of Thija agrees with Land's description. The organization of the ventral canal-nucleus takes place in identically the same manner as in the former species. Fig. Ig shows the position of the central nucleus during its division. Fig. 2 I represents the spindle of this mitosis more highly magnified. Fig. 20 indicates the relative position of the egg-nucleus and ventral canal-nucleus some time after the organization of the latter. It will be noticed that the egg-nucleus has enlarged considerably.

Enveloping the archegonial complex in Libocedrus-and this is true 
also for the other Cupressineae which I have investigated-there is a single layer of jacket-cells. Compared with those of other Gymnosperms these cells are poorly developed, being very small, while the walls separating them from the central cell are almost as thin as the walls of the ordinary endospermcells. They become differentiated as jacket-cells quite early-before the neck-cells are formed-and soon become filled with a dense cytoplasm, due no doubt to the accumulation of food substances, and as a consequence stain much more deeply than the neighbouring cells. With the growth of the archegonia the jacket-cells divide and increase in number, but their multiplication ceases when the central cells have reached their full size. Many of them at this time are binucleate, a peculiarity which has also been observed in Taxodium (Coker, '04). In Cryptomeria they may even be multinucleate (Lawson, '04). The general appearance and distribution of the jacket-cells may be seen in Pl. XXV, Figs. I6, I8, and Pl. XXVI, Figs. 25 and 30.

The relationship of these jacket-cells to the nutrition of the egg has been a matter of much discussion for the Gymnosperms in general, especially since Arnoldi ('00) described and figured the actual passage of the jacket-cell nuclei through the cell-walls and into the cytoplasm of the egg, thus giving rise to the structures known as 'proteid-vacuoles.' This subject has, however, been thoroughly investigated quite recently by Stopes and Fujii ('06) in the case of the Cycads, Ginkgo and Pinus, and also by Chamberlain ('06) in the case of Dioon. From the account given by Stopes and Fujii it appears that the thick wall between the jacket-cells and the egg is pitted, but each pit is closed by a thin membrane which is perforated only by 'plasmodesmen.' They therefore point out the impossibility of nuclei, starch grains, or protein grains being transferred bodily from the jacket-cells into the egg. They further suggest that the jacket-cells are glandular or secretory, and render the storage food of the endosperm soluble and available for absorption by the developing egg-cell. In the case of Dioon, however, Chamberlain demonstrates a distinct communication between the jacket-cells and the egg in the form of cytoplasmic haustoria.

While the conclusions reached by these later writers are much more rational than any offered by previous investigators, their explanations do not seem entirely applicable to the conditions found in the Cupressineae. As I have stated above, in this latter group the wall separating the egg from the jacket-cells shows very little thickening, and I was unable to detect any cytoplasmic communication between them. I should also like to point out that in all of the Cupressineae, on account of the grouping of the archegonia in a single complex, many of the egg-cells do not come in contact with the jacket-cells at all. As clearly shown in Figs. I6, I7, I8, and 25 the egg-cells that are centrally situated are surrounded completely by neighbouring egg-cells. The cytoplasm of these centrally situated eggcells showed very little difference in the character and quantity of food 
granules from that of the egg-cells in contact with the nourishing jacket-cells. It therefore seems rational to assume that the manner of transference of food substances from egg-cell to egg-cell is the same as that from jacket-cell to egg-cell. In the thin walls separating the egg-cells from each other I was unable to detect any evidence of pits or perforations, and I therefore believe that all food substances carried into the egg are translocated in soluble form. In this connexion it may be worth while calling attention to the fact that a large vacuole, situated just below the egg-nucleus, is a constant character of the archegonium of all of the Cupressineae which I have examined (see Figs. 16, 20, and 25). It seems not improbable that the osmotic activities which these vacuoles must necessarily set up have much to do with the absorption of food substances in solution from the surrounding endosperm, and also from egg-cell to egg-cell. The sum total of the osmotic activities set up by twenty or more large, closely situated vacuoles must be considerable. In the Cupressineae, however, the archegonia and the manner of their grouping are highly specialized, and it is therefore not surprising to find the method of their nutrition somewhat different from such primitive types as the Cycads, Ginkgo, or the Abietineae.

\section{Fertilization.}

In the Podocarpeae (Coker, '02), Taxeae (Jäger, '99; Belajeff, '93 ; Robertson, '04; ; Lawson, '07), and Abietineae (Blackman, '98 ; Coulter and Chamberlain, '01 ; Ferguson, '01) the archegonia are few in number, and are not grouped closely together, but each is separated from its neighbour by prothallial tissue, and each possesses a small independent archegonial chamber leading to the neck. When the pollen-tube reaches one of these archegonial chambers its entire contents are discharged into the archegonium, and it is thus possible for only one archegonium to be fertilized by one pollen-tube-or in other words, only one of the two male gametes can be functional. The effect of this arrangement of the archegonia finds an expression in the form of the male gametes. For instance, in Podocarpus (Coker, '02) these structures are represented by a large male cell and a dwarfed male nucleus which does not function. In Taxus (Jäger, '99), and also in Torreya taxifolia (Coulter and Land, '05), there are two male cells organized, but one of them is much smaller than the other, and only the latter is functional. In Cephalotaxus (Lawson, ' 07 ) the male gametes are reduced to nuclei, both of which enter the archegonium, but only one unites with the egg-nucleus. In Picea and Abies (Miyake, '03), and also in Pinus (Ferguson, '01), the male cells are likewise represented only by nuclei, but in these forms the sperm nuclei are of unequal size, and it is only the larger one which is functional.

When we come to the Cupressineae, however, we find that the archegonia are grouped together in a single complex, with their necks exposed 
at the base of a large common archegonial chamber. It is into this chamber that the contents of the various pollen-tubes are discharged. The archegonia being quite numerous, conditions are such that both male gametes from each tube may be functional. The effect of this arrangement likewise finds an expression in the form of the male gametes; for in all of the $\mathrm{Cu}$ pressineae which have been investigated, namely, Taxodium, Cryptomeria, Thuja, Libocedrus, Chamaecyparis, Cupressus, and Fumiperus, these structures take the form of two large male cells of equal size. This more primitive condition of the male cells is, however, not confined to this group, for we know that the male cells in Sequoia are very similar to those of the Cupressineae, but in this genus also the position of the archegonia in relation to the pollen-tubes is such as to permit of both male gametes functioning.

By the time the male cells and other structures of the tip of the pollentube have been discharged into the archegonial chamber, the neck-cells seem to disintegrate, leaving a free passage for the sperm-cells to enter the archegonia This was observed in both Libocedrus and Thuja orientalis. Pl. XXV, Fig. $I 7$ is a section through the archegonial chamber at this time. One male cell may be seen about to enter an archegonium. The actual entrance of the male cell into the egg was not observed in Libocedrus, but in Thuja and Chamaecyparis a complete series of fertilization stages was obtained. In both of these forms but a single male cell was observed to enter the egg with an occasional stalk- or tube-nucleus. In no preparation was I able to find more than one male nucleus in the egg, as sometimes seems to be the case in Taxodium (Coker, '04). As many archegonia may thus be fertilized as there are male cells organized in the various pollen-tubes. Upon entering the archegonium the nucleus of the male cell escapes from its surrounding cytoplasm and advances immediately towards the egg-nucleus. The male cytoplasm advances in the same direction, but more slowly, as indicated in Pl. XXVI, Figs. 26 and 27. The egg-cytoplasm between the advancing male nucleus and the neck did not show that vacuole-like disturbance which is so characteristic of this stage in certain of the Abietineae and in Cephalotaxus, and this fact supports the statement made above that the tip of the pollen-tube does not enter the egg. As shown in Figs. 26, 27, and 28, the male nucleus presses closely into the membrane of the female, and the former, at this time, is less than half the size of the latter. There is not only a difference in the size of the sex nuclei, but the chromatic contents of the male are very unlike those of the female. The male chromatin is in the form of very small granules of uniform size, apparently supported on linin, forming a network of granular threads, as shown in Fig. 28. With the female nucleus, however, it was quite impossible to distinguish the true chromatin from the nucleoli and other irregularly shaped bodies which stained like chromatin and seemed to be closely associated with the latter. The two nuclei now enlarge considerably - the male more than the female- 
and, as indicated in Fig. 29, their chromatic contents come to resemble each other more closely as to their structure. As shown in this figure, the membrane between the nuclei persists for some considerable time. During the process of fusion the granular, starch-containing cytoplasm from the male cell completely envelopes both nuclei. In the great difference in size of the sex nuclei at the time when they first come together, Chamaecyparis, Thuja (Land, '02), Cupressus, Taxodium (Coker, '04), and Cryptomeria (Lawson, '04) present conditions similar to those found in the Abietineae (Blackman, '98; Woycicki, '99 ; Coulter and Chamberlain, '01 ; Ferguson, '01 ; Miyake, '03; Murrill, '00), and in the Taxeae (Robertson, '04; Coulter and Land, '05 ; Lawson, '07). These conditions differ, however, from those found in Sequoia (Lawson, '04), for here the male nucleus is quite large at the time of its entrance into the egg.

In none of my preparations was I fortunate enough to find stages showing the formation of the first cleavage spindle, and I am therefore not in a position to give an account of the behaviour of the male and female chromosomes, or of the stage at which these elements lose their identity. From an examination of the early stages of the embryo in Thija, Libocedrus, Chamaecyparis, and Cupressus, I can say without much doubt that this spindle is organized in the middle region of the archegonium in just about the same place where the fusion of sex nuclei took place. In this I agree with Land's ('02) observations on Thija occidentalis, but cannot confirm Coker's ('04) account of Taxodium, where the fusing nuclei are reported as sinking to the base of the archegonium before the first division occurs.

\section{The EMbryo.}

In Libocedrus, Cupressus, Chamaecyparis, and Thija the first division of the fusion nucleus takes place near the centre of the archegonium. The two free nuclei resulting from this division come to lie very close together, and are enveloped in a granular, deeply staining sheath which seems to consist mainly of starch. In this condition the first two nuclei of the pro-embryo move towards the base of the archegonium, as indicated in Fig. $3^{\circ}$. It is very probable that some of this starch comes from the male cytoplasm, but that all of it comes from this source seems quite as improbable, for by the time the free nuclei have reached the base of the archegonium the amount of starch surrounding the pro-embryo has increased enormously. Fig. 32 shows the pro-embryo of Libocedrus with the two daughter-nuclei of the

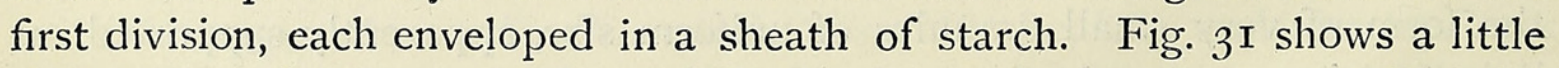
older stage of the pro-embryo of Thuja, where the starch surrounding the two nuclei has increased to such an extent that it seems to completely fill the basal region of the archegonium in which the embryo is about to be developed. When the conditions shown in Fig. 3I has been reached, the first two nuclei of the embryo prepare for mitosis, and as shown in Fig. 33 
they divide simultaneously. It will also be seen from this figure that the two spindles of this division lie one behind the other, with their long axes parallel with the long axis of the archegonium. The four daughter-nuclei resulting from this division are thus arranged in a single row, and not in the tetrad fashion as seems to be the case at this stage in Taxodium (Coker, '03). Land ('02) also figures a somewhat different position of the spindles of the second division in Thuja occidentalis. As only two or three preparations showed this stage of the embryo, I cannot say how constant or variable the position of the first four nuclei may be, but judging from the stage just before the third division, and also from a study of these stages in Cryptomeria, I am inclined to believe that there may be a considerable variation in the position of the free nuclei up to the time they arrange themselves in tiers and definite walls are formed between them.

Some time before and during the second division the archegonium becomes differentiated into two distinct regions, and this seems to be brought about by the sinking of all the starch, 'proteid-vacuoles,' and other food substances into the basal region of the fertilized egg in very much the same manner as that which I have reported for Cephalotaxus (Lawson, '07). It is only this nutritive or basal region of the archegonium which now concerns the development of the embryo, and this is indicated in Figs. 3I, 33,34 , and 35 .

No sooner are the first four nuclei organized than they prepare for the third mitosis. This latter division is also simultaneous, and it results in the formation of eight free nuclei in the pro-embryo. From Land's ('02) account of the embryo of Thija; Coker's ('03) account of Taxodium, and my own observations on Cryptomeria, Thuja, Libocedrus, and Cupressus, it seems that the organization of eight free nuclei in the pro-embryo, before the formation of cell-walls, is a constant feature of the Cupressineae.

Fig. 34 shows a stage just previous to the formation of the first cellwalls of the embryo. These walls are obviously formed in the same manner as they are in Cryptomeria (Lawson, '04). The spindles of the first two divisions disappear entirely after the organization of the daughter-nuclei, but the continuous fibrils of the spindles of the third division persist until membranes are formed from them midway between the nuclei. The cells of the pro-embryo, as a result of these divisions, are arranged in three distinct tiers-or rather two tiers of cells and one tier of free nuclei, for the upper tier or rosette are not surrounded by walls. The middle tier of cells very soon begin to elongate, and are thus easily identified as suspensors. The end tier of cells or embryo cells proper show very little enlargement, and no more merismatic activity whatever until they have been carried for a considerable distance into the endosperm tissue by the enormous elongation of the suspensors. In this regard Libocedrus and other Cupressineae are very unlike that of Cephalotaxus, for in this latter genus the embryo cells 
become very numerous before the suspensors elongate (Lawson, '07). In this latter case, however, the work of the suspensors in carrying the embryo into the endosperm is supplemented by a penetrating cap formed from the tip cells of the embryo.

The further development of the embryo in Libocedrus agrees in all essential details with that which I have described for Cryptomeria (Lawson, '04), and closely resembles the account given by Land ('02) in the case of Thuja. Fig. $3^{6}$ shows an embryo of Libocedrus with the middle tier of suspensor cells considerably elongated, and a group of embryo cells proper at the tip. The nuclei of the rosette may also be seen in the cytoplasm of the archegonium above. Fig. 37 represents a still later stage in the development of the suspensors.

\section{Summary AND Conclusion.}

From investigations on the pollen of Taxodium, Cryptomeria, Thuja, Libocedrus, Chamaecyparis, Cupressus, and Funiperus, it seems that the microspores of the Cupressineae are characterized by the absence of vestigial prothallial cells or of nuclei representing such cells.

The mature microspore consists of two cells, containing respectively the generative and tube-nuclei.

With the exception of Cupressus and Funiperus, the first division of the microspore, which gives rise to the generative and tube-nuclei, takes place before pollination.

By the time the pollen-tube has penetrated the nucellar tissue the generative nucieus enlarges and divides. As a result of this division the body-cell and stalk-nucleus are organized.

The growth of the pollen-tube is almost in a straight line towards the archegonial chamber, and as it advances the body-cell and stalk- and tube-nuclei are always found at the tip.

When the archegonial chamber has been reached the body-cell divides, giving rise to two large male cells of equal size.

The case reported by Juel for Cupressus Goweniana, where the bodycell gives rise to a cell complex, is regarded as an abnormality.

The number of megaspore mother-cells formed may vary from one to three, each of which divides twice. Only one of the resulting megaspores germinates.

The presence of a tapetum surrounding the megaspore seems to be characteristic of the group, but it varies considerably as to the extent of its development in the different genera studied.

The functioning megaspore first enlarges, and this is followed by rapid free nuclear division. A number of vacuoles now make their appearance, but as the spore enlarges these flow together, forming a very large central 
vacuole which forces the cytoplasm and numerous free nuclei to the periphery. The parietal layer of cytoplasm consists of a mere film in which the free nuclei are distributed at intervals.

Free nuclear division now proceeds, and the amount of cytoplasm also increases. It is believed that the osmotic activities set up by the central vacuole have much to do with the absorptions of food materials from the surrounding nucellar tissue.

As the amount of cytoplasm increases, free nuclear division ceases, and walls are formed between the nuclei. The primary prothallial cells thus formed are open and exposed to the sap of the vacuole on the inner side. The primary cells now elongate rapidly, and by their inward growth the space occupied by the central vacuole is eventually closed. During their growth numerous cross-walls are formed in the primary cells, but those on the inner side always remain open until the vacuole vanishes.

A poorly developed megaspore membrane is characteristic of all the Cupressineae examined.

The archegonia vary in number from six or eight to twenty-four, and are always grouped closely together in a single complex. There is a common large archegonial chamber, at the base of which the necks of the archegonia lie closely clustered together. A single layer of jacket-cells surrounds the archegonial complex.

In none of the Cupressineae is there a ventral canal-cell formed. This structure is represented only by a nucleus.

The contents of the various pollen-tubes become discharged into the archegonial chamber, and as the archegonia are numerous it is thus possible for both male cells from each pollen-tube to function. One pollen-tube may fertilize two separate archegonia.

As a rule one male cell enters the egg, and its nucleus slips from its cytoplasm and unites with the egg-nucleus. When the sex nuclei first come in contact with each other the female is three or four times the size of the male.

The first spindle of the sporophyte is organized near the middle of the archegonium, in the same place where the fusion of the sex nuclei occurred. After the first division the two free nuclei of the pro-embryo become enveloped in a sheath of starch, and move towards the base of the archegonium. In this position they divide, and this is immediately followed by a third division resulting in the formation of eight free nuclei before any cell-walls are formed.

The cells of the pro-embryo become arranged in three tiers-the upper forming the rosette, the middle tier which develops into the suspensors, and the group of cells at the tip which form the embryo proper.

Considering the state of development of all the various vestigial structures associated with the gametophytes, and comparing them with 
other Conifers, the Cupressineae cannot be regarded as a very primitive group. They certainly do not present as many primitive characters as the Abietineae, but on the other hand they are more primitive than Cephalotaxus.

\section{LiterATURE Cited.}

Arnoldi, W. ('00): Beiträge zur Morphologie der Gymnospermen: III. Embryogenie von Cephalotoxus Fortunei. Flora, lxxxvii, p. 46, I900.

('00): Beiträge zur Morphologie einiger Gymnospermen: I. Die Entwicklung des Endosperms bei Sequoia sempervirens. Bull. Soc. Imp. Nat. Moscou, I 900.

('00): Beiträge zur Morphologie und Entwicklungsgeschichte einiger Gymnospermen : II. Ueber die Corpuscula und Pollenschläuche bei Sequoia sempervirens. Bull. Soc. Imp. Nat. Moscou, 1900.

('01) : Beiträge zur Morphologie einiger Gymnospermen : V. Weitere Untersuchungen über die Embryologie in der Familie der Sequoiaceen. Bull. Soc. Imp. Nat. Moscon, I90I.

Belajeff, W. ('93): Zur Lehre von dem Pollenschlauche der Gymnospermen. Ber. der Deutsch. Bot. Gesell., ii, p. 196.

Blackman, V. H. ('98): On the Cytological Features of Fertilization and Related Phenomena in Pinus silvestris, L. Phil. Trans. Roy. Soc., cxc, p. 395.

Chamberlain, C. J. ('06): The Ovule and Female Gametophyte of Dioon. Bot. Gaz., xlii, p. $32 \mathrm{I}, 1906$.

Coker, W. C. ('02): Notes on the Gametophytes and Embryo of Podocarpus. Bot. Gaz., xxxiii, p. 89.

('03): The Gametophytes and Embryo of Taxodium. Bot. Gaz., xxxvi, pp. I-27 and II $4-40$.

('04): On the Spores of Certain Coniferae. Bot. Gaz., xxxviii, p. 206, 1904.

Coulter, J. M., and Chamberlain, J. C. ('01): Morphology of Spermatophytes, Part I. New York, I901.

Coulter, J. M., and Land, W. J. G. ('05): Gametophytes and Embryo of Torreya taxifolia. Bot. Gaz., xxxix, p. 161, 1905 .

Dixon, H. N. ('94) : Fertilization in Pinus silvestris. Ann. Bot., viii, p. 2 r.

Ferguson, M. C. ('01): The Development of the Pollen-tube and the Division of the Generative Nucleus in certain species of Pinus. Ann. Bot., xv, p. 193.

Bot., $x v$, p. 435 .

Goroschankin, J. ('83): Zur Kenntniss der Corpuscula bei den Gymnospermen. Bot. Zeit., xli, p. 825 .

Hirase, S. ('95): Études sur la fécondation et l'embryogénie du Ginkgo biloba. Jour. Coll. Sci. Imp. Univ. Tokyo, viii, p. 307 .

Ikeno, S. ('96): Das Spermatozoid von Cycas revoluta. Bot. Mag. Tokyo, x, p. 367 .

JÄGER, L. ('99): Beiträge zur Kenntniss der Endospermbildung und zur Embryologie von Taxus baccata. Flora, lxxxvi, p. $24 \mathrm{I}$.

Jefrrey, E. C. ('03 and '05) : Comp. Anatomy and Phylogeny of the Coniferales. Part I, Sequoia ; Part II, Abietineae. Mem. Boston Soc. Nat. Hist., vols. 5 and 6.

Jusi, H. O. ('00) : Beiträge zur Kenntniss der Tetradentheilung. Jahrb. f. wiss. Bot., xxxv, p. 626, I900.

('04): Ueber den Pollenschlauch von Cupressus. Flora, xciii, p. 56, 1904.

LAnd, W. J. G. ('02): A Morphological Study of Thrija. Bot. Gaz., xxxvi, p. 249.

Lawson, A. A. ('04): The Gametophytes, Archegonia, Fertilization, and Embryo of Sequoia sempervirens. Ann. Bot., xviii, no. lxix, p. I, $190_{4}$. 
Lawson, A. A. ('04): The Gametophytes, Fertilization, and Embryo of Cryplomeria japonica. Ann. Bot., xviii, no. lxxi, 1904 .

('07): The Gametophytes, Fertilization, and Embryo of Cephalotaxus drupacea. Ann. Bot., xxi, no. 1xxxi, 1907 .

Mryake, K. ('03): On the Development of the Sexual Organs and Fertilization of Picea excelsa. Ann. Bot., xvii, p. 66.

('03): Contribution to the Fertilization and Embryogeny of Abies balsama. Beihefte zum Bot. Cent., xiv, p. I $34,19 \circ 3$.

MURRILL, W. A. ('00): The Development of the Archegonium and Fertilization in the Hemlock Spruce (Tsuga canadensis). Ann. Bot., xiv, p. $5^{83}$.

Robertson, A. ('04): Spore formation in Torreya Californica. New Phyt., iii, p. I33, I904.

('04): Studies in the Morphology of Torreya Californica. New Phyt., iii, p. 205, 1904.

Shaw, W. R. ('96): Contribution to the Life-history of Sequoia sempervirens. Bot. Gaz., xxi, p. 332.

Sokolowa, Mlle C. ('90): Naissance de l'endosperme dans le sac embryonnaire de quelques Gymnospermes. Bull. Soc. Imp. Nat. Moscou, 1890 (189I), p. 446.

Strasburger, E. ('72): Die Coniferen und Gnetaceen, 1872.

('79): Die Angiospermen und die Gymnospermen, 1879 .

('84): Neue Untersuchungen über die Befruchtungsvorgänge bei den Phanerogamen als Grundlage für eine Theorie der Zeugung. Jena, I $88_{4}$.

('92): Ueber das Verhalten des Pollens und die Befruchtungsvorgänge bei den Gymnospermen. Hist. Beit., iv, P. I, I892.

Stopes, M. C., and FujiI, K. ('06): The Nutritive Relations of the surrounding Tissues to the Archegonium in Gymnosperms. Beihefte zum Bot. Cent., Bd. xx, Heft I, 1906.

Thomson, R. B. ('05) : The Megaspore-membrane of the Gymnosperms. Univ. Toronto Studies, Biol. Series, iv, 1905 .

Webber, H. J. ('97): Peculiar Structure in the Pollen-tube of Zamia. Bot. Gaz., xxiii, p. 453.

('97): The Development of the Antherozoids of Zamia. Bot. Gaz., xxiv, p. I6.

('97): Notes on the Fecundation of Zamia and the Pollen-tube Apparatus of Ginkgo. Bot. Gaz., xxiv, p. 225.

('01): Spermatogenesis and Fecundation of Zamia. U.S. Dept. Agri. Bur. of Plant Industry. Bull., ii, I90I.

Woycicki, Z. ('99): Fertilization in the Coniferae. Warsaw, 1898. Reviewed in Journ. Roy. Micro. Soc., p. 482 , 1900.

\section{EXPLANATION OF FIGURES IN PLATES XXIV-XXVI.}

\section{Illustrating Dr. Lawson's Paper on the Cupressineae.}

All figures were drawn with the aid of the camera lucida. The following oculars and objectives were used :-

Figs. I, 2, 8, Zeiss. oc. 6, obj. $16 \mathrm{~mm}$.

Figs. 3, 33, 35, Zeiss. oc. 2, obj. $3 \mathrm{~mm}$.

Figs. 4, 5, 6, 7, 28, Zeiss. oc. I, obj. $\frac{1}{12}$ oil imm.

Figs. 9, 10, 11, 12, 29, Zeiss. oc. 2, obj. $\frac{1}{12}$ oil imm.

Figs. I 3, I5, Zeiss. oc. 4, obj. I $6 \mathrm{~mm}$.

Figs. 14, 21, 22, 23, 24, Zeiss. oc. 4, obj. $\frac{1}{12}$ oil imm.

Fig. 27 , Zeiss. oc. 3 , obj. $\frac{1}{7}$ oil imm.

Figs. 33,35 , Zeiss. oc. 2, obj. $\frac{1}{3}$ oil imm.

Figs. I6, I 7, 18, 19, 20, 25, 26, 30, 31, 33, 34, Zeiss. oc. 6, obj. $\frac{1}{3}$ oil imm.

Fig. I. A longitudinal section through the upper part of the nucellus showing a young pollentube. Thuja orientalis. May $\mathbf{1} 2$.

Fig. 2. The same at a later stage showing at least four pollen-tubes. May 22. 
Fig. 3. A longitudinal section through the end of a pollen-tube showing the body-cell and tube-nucleus. Thuja orientalis. May 27.

Fig. 4. The contents of the tip of an older pollen-tube showing the body-cell and stalk- and tube-nuclei. Thuja orientalis. May 22.

Fig. 5. A section of one of the male cells just befo:e fertilization. May 27.

Fig. 6. A section of the body-cell some time before the final division which gives rise to the two male cells. Libocedrus decurrens. May $3 \mathbf{I}$.

Fig. 7. Two male cells some time before fertilization. Libocedrus decurrens. June $\mathrm{I}$.

Fig. 8. A longitudinal section of a young megasporangium showing two megaspore mothercells. Libocedrus decurrens, March 22.

Fig. 9. A section of two megaspore mother-cells more highly magnified. Libocedrus decurrens. March 23.

Fig. Io. A section of four megaspores just after the first division of the mother-cells. Libocedrus decurrens. March 23.

Fig. II. A section showing six of the eight megaspores after the second division. Libocedrus decurrens. March 23.

Fig. 12. A section of a megaspore some time after germination showing numerous free nuclei in process of division. Libocedrus decurrens. April i3.

Fig. 13. A section through the lower half of a young female prothallium showing the large central vacuole and parietal layer of cytoplasm in which numerous free nuclei lie embedded. Libocedrus decurrens. May 8.

Fig. I4. A section of the parietal layer of cytoplasm more highly magnified and taken from the stage shown in Fig. 13. Libocedrus decurrens. May 8.

Fig. 15. A longitudinal section of the lower half of a young female prothallium showing the inward growth of the primary prothallial cells and the consequent diminution in the size of the central vacuole. The nuclei are much more numerous at the periphery of the cells exposed to the fluid of the vacuole. Thuja orientalis. May I I.

Fig. I6. A longitudinal section through an arehegonial complex showing the single layer of jacket-cells surrounding the whole group. Thija orientalis. May zo.

Fig. 17. A longitudinal section of an archegonial complex showing a portion of the archegonial chamber above, into which the contents of the pollen-tubes have been discharged. Thuja orientalis. May 30.

Fig. 18. A cross-section of an archegonial complex showing the common jacket surrounding twenty-three archegonia. Thuja orientalis. May 22.

Fig. 19. A longitudinal section of an archegonium showing the central nucleus undergoing division. Thuja orientalis. May 30 .

Fig. 20. A longitudinal section of an archegonium showing the position of the ventral canalnucleus and the egg-nuclens. Thuja orientalis. May zo.

Fig. 2I. A more highly magnified section of the spindle which gives rise to the egg-nucleus and ventral canal-nucleus. Thuja orientalis. May 30.

Fig. 22. A section of the spindle which gives rise to the ventral canal-nucleus and egg-nucleus. Libocedrus decurrens. June $\mathrm{I}$.

Fig. 23. A more highly magnified section showing the ventral canal-nucleus and egg-nucleus just after the division of the central cell. Thuja orientalis. May 30.

Fig. 24. A later stage of the same showing the absence of any trace of a membrane between the two nuclei. May 30.

Fig. 25. A longitudinal section through an archegonial complex just before fertilization. Liliocedrus decurrens. June 6.

Fig. 26. An archegonium showing the fusion of the male and female nuclei. Thuja orientalis. May 30.

Fig. 27. A more highly magnified view of a similar stage showing the presence of the male cytoplasm above the fusing nuclei, and also the presence of numerous so-called 'proteid-vacuoles.' May 30.

Fig. 28. A section of the male and female nuclei in process of fusion showing their relative size and the difference in the structure of their chromatic contents Thuja orientalis. May 30.

Fig. 29. A later stage of the same showing the increase in size of the male nucleus and the similarity in the structure of the chromatic contents of both nuclei. May 30. 
Fig. 30. A longitudinal section of an archegonial complex showing three pro-embryos with a zone of starch surrounding each. Libocedrus decurrens. June $\mathrm{I}$.

Fig. 3r. A pro-embryo showing the accumulation of starch and other granular substances in the basal region of the archegonium. Thuja orientalis. May 30.

Fig. 32. A pro-embryo after the first division showing the two nuclei surrounded by a dense zone of starch. Libocedrus decurrens. June I.

Fig. 33. A later stage of the pro-embryo with the two free nuclei undergoing division. Libocedrus decurrens. June $\mathrm{I}$.

Fig. 34. A later stage of the pro-embryo with eight free nuclei. Thuja orientalis. May 30.

Fig. 35. A pro-embryo of eight free nuclei with no cell-walls separating them. Libocedrus decurrens. June $\mathbf{I}$.

Fig. 36 . An embryo showing the elongation of the middle tier of cells to form the suspensors. Libocedrus decurrens. June I.

Fig. 37. A later stage of the same showing the suspensors more fully developed. Libocedrus decurrens. June 2. 



4.

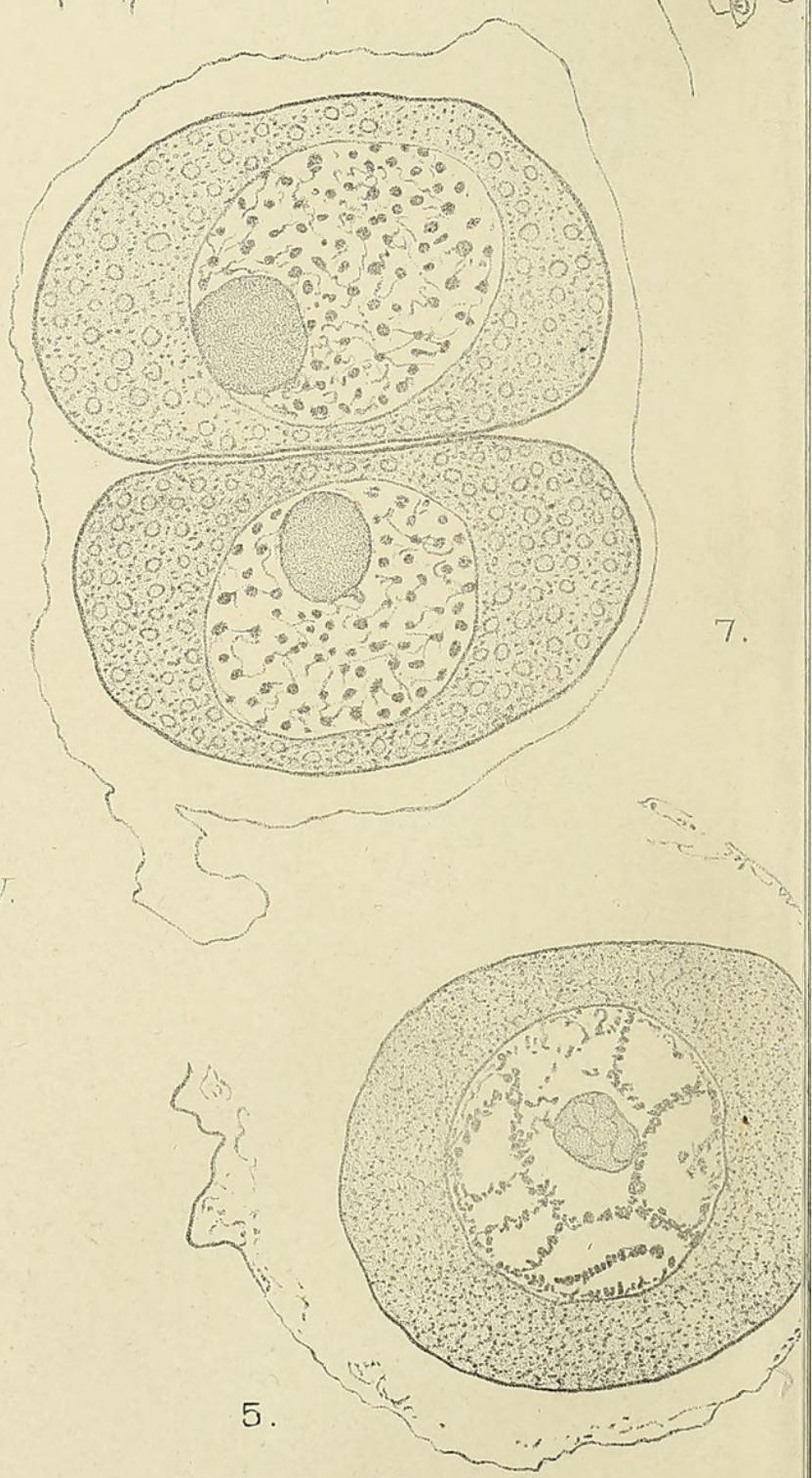




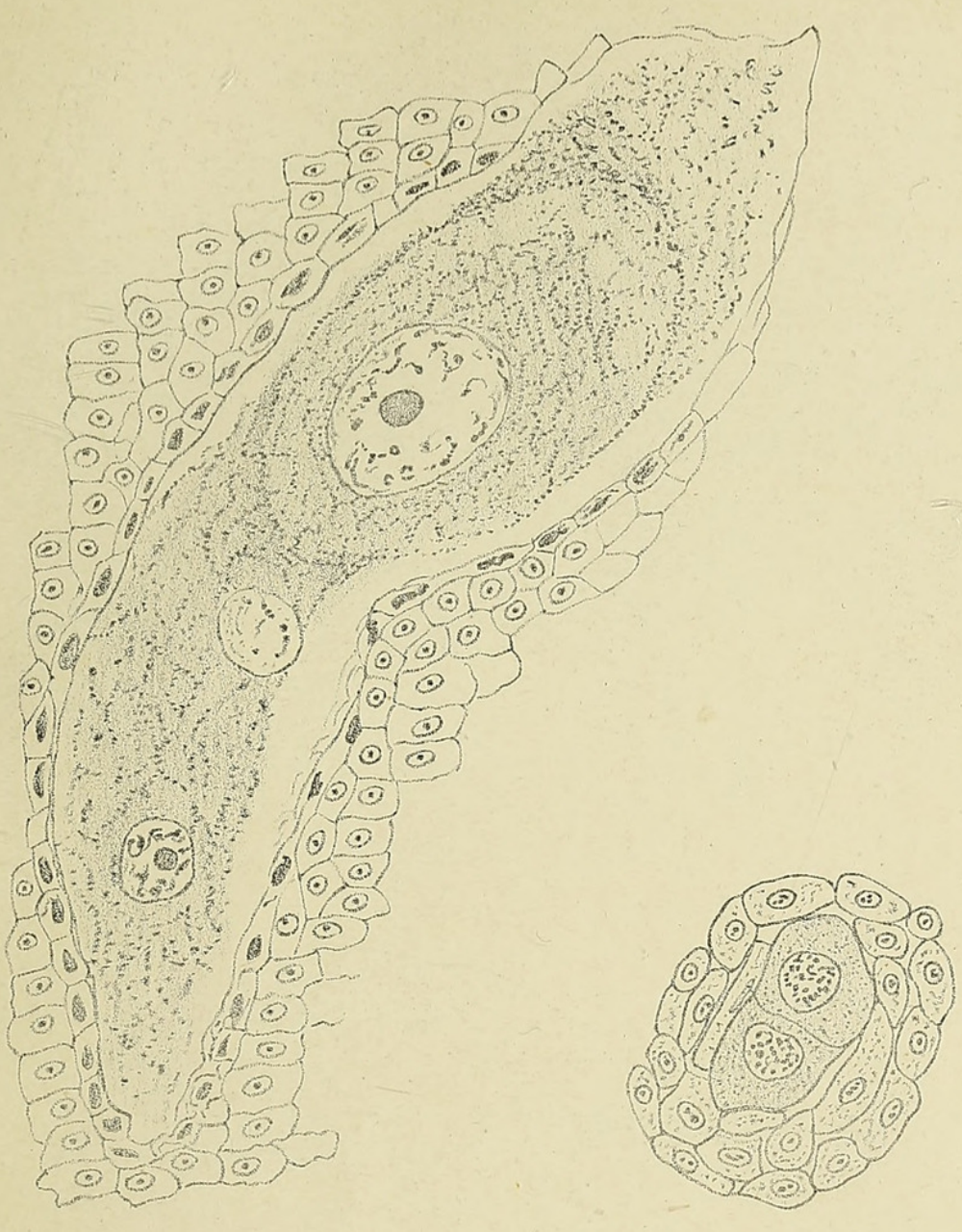

3
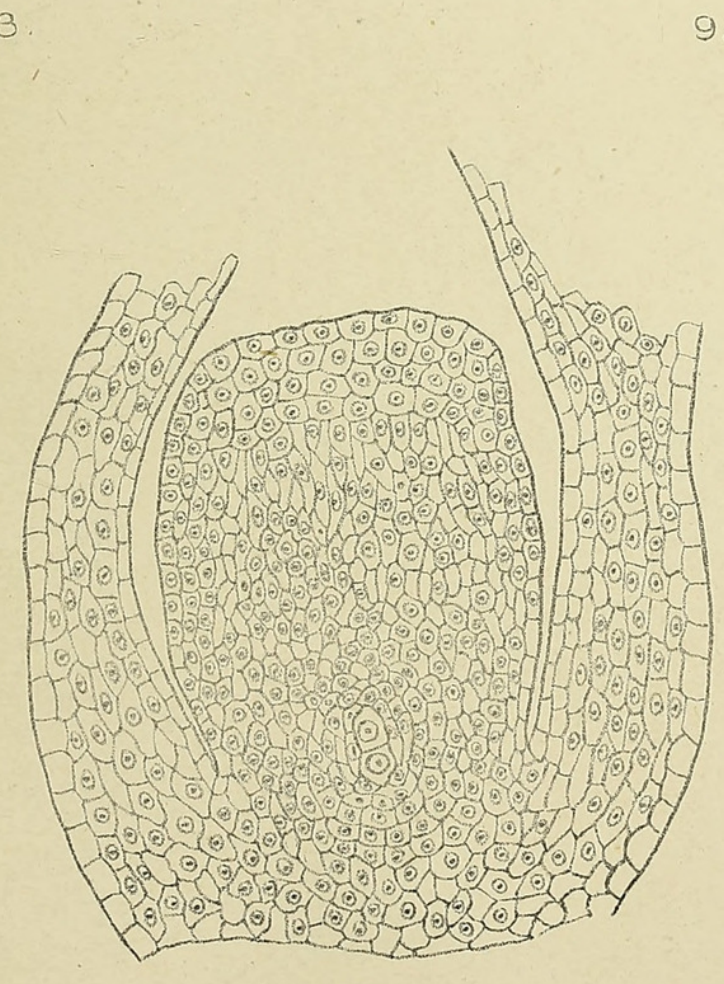

8.
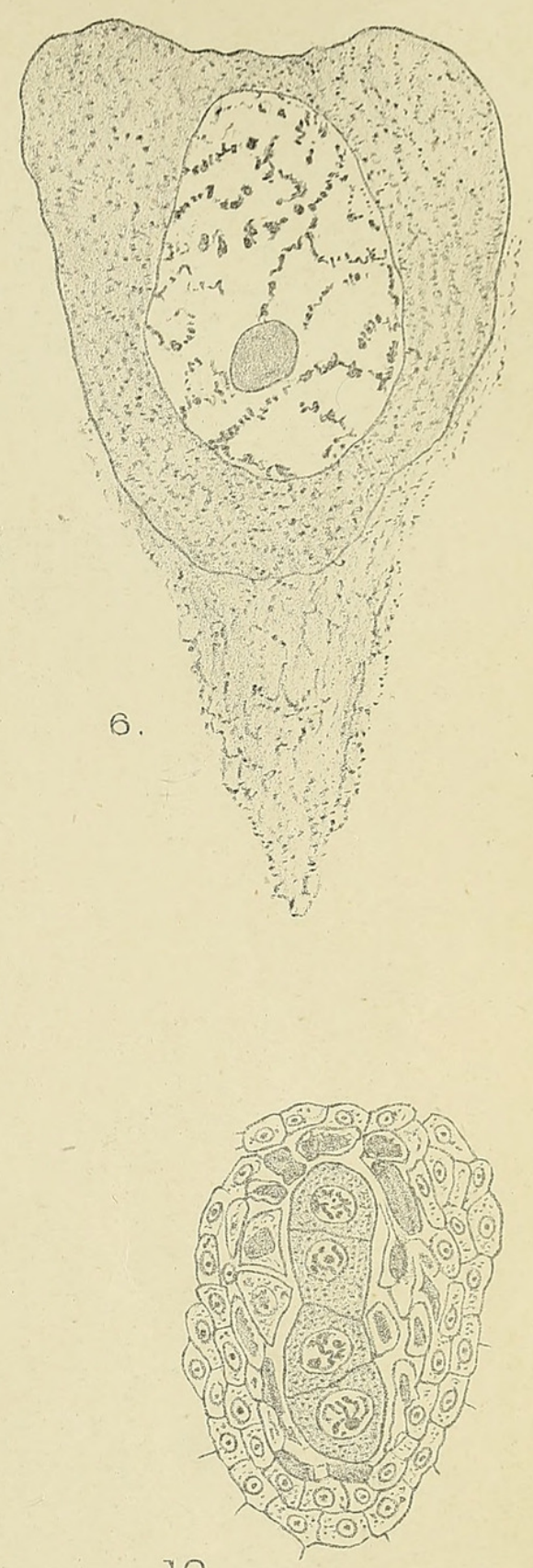

10

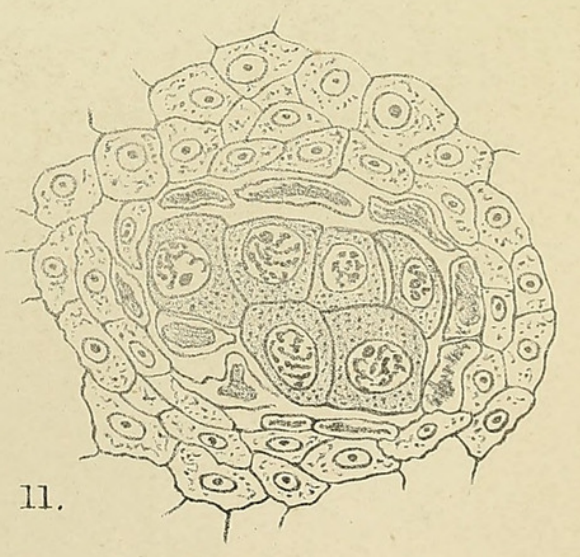

Huth lith, et imp. 

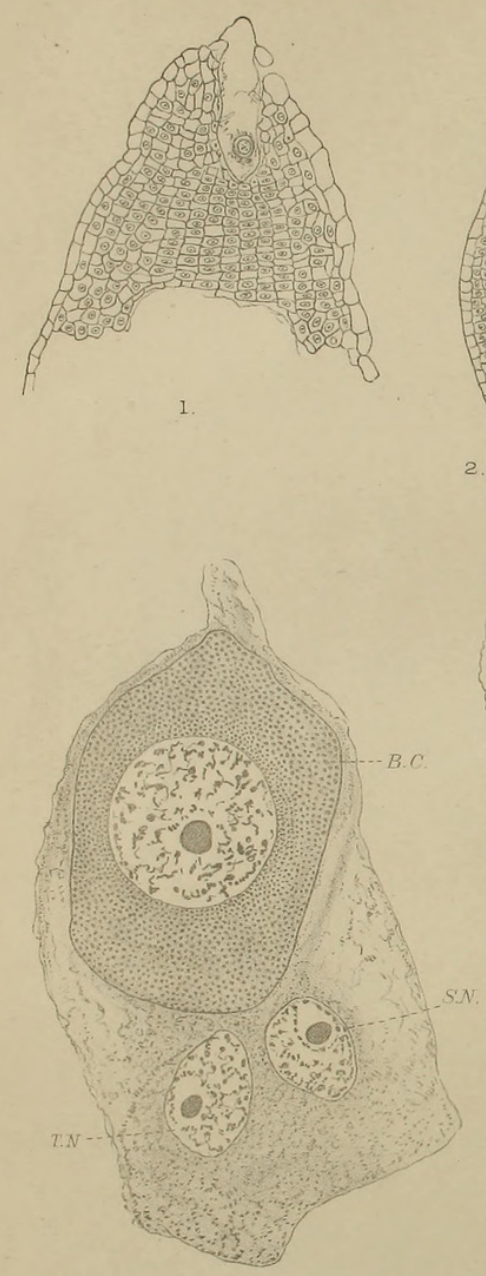

4.
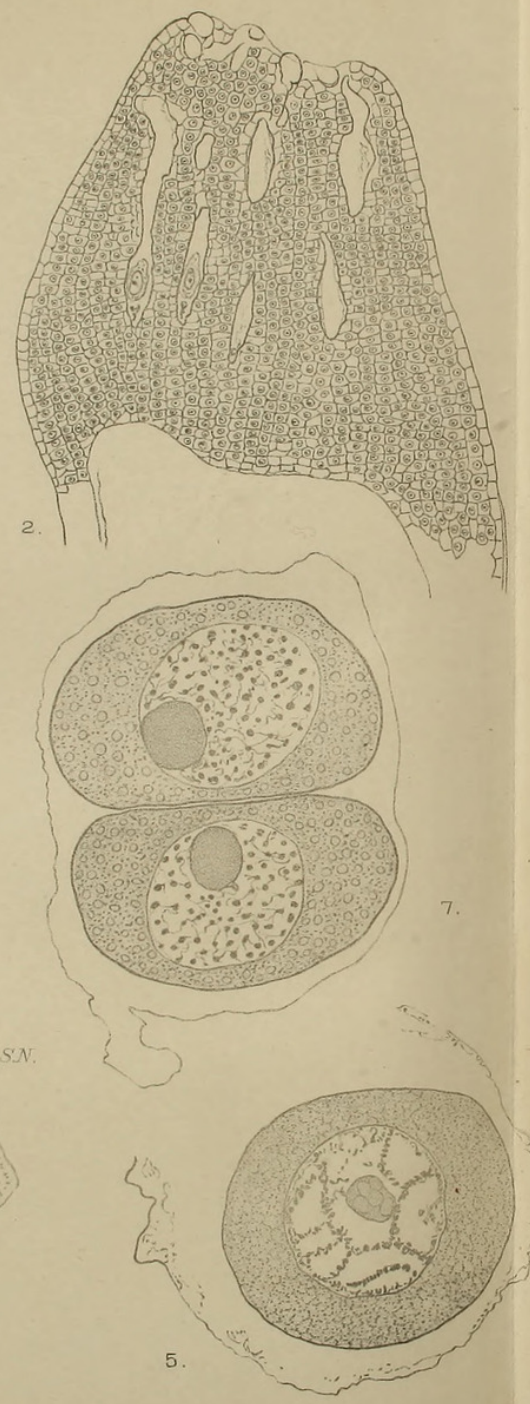

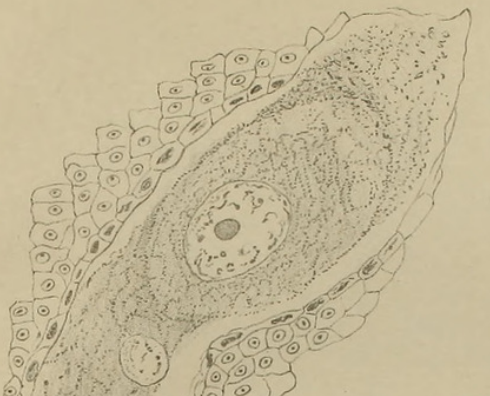

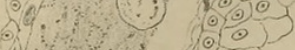

(1) $\quad 1 \% \frac{0}{0}$

(1) $1,350 \% 0$

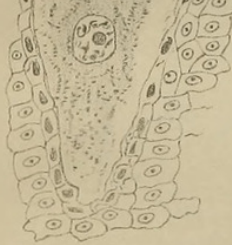

3

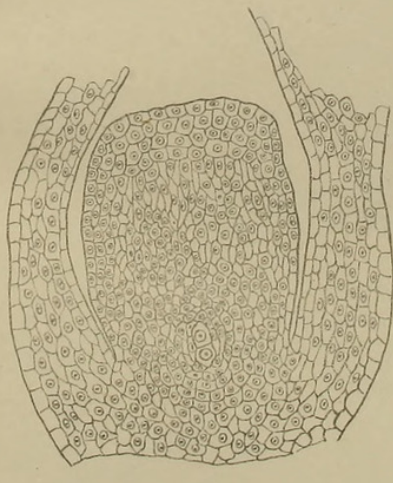

8.
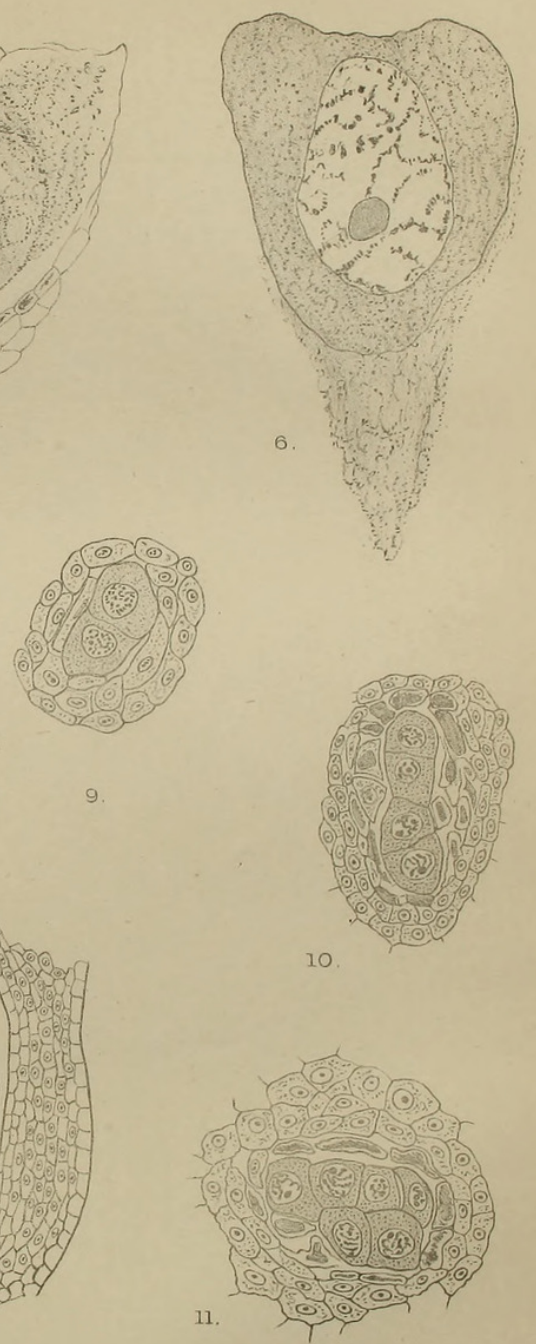

Huth lith. et imp. 
Annats of Botany.
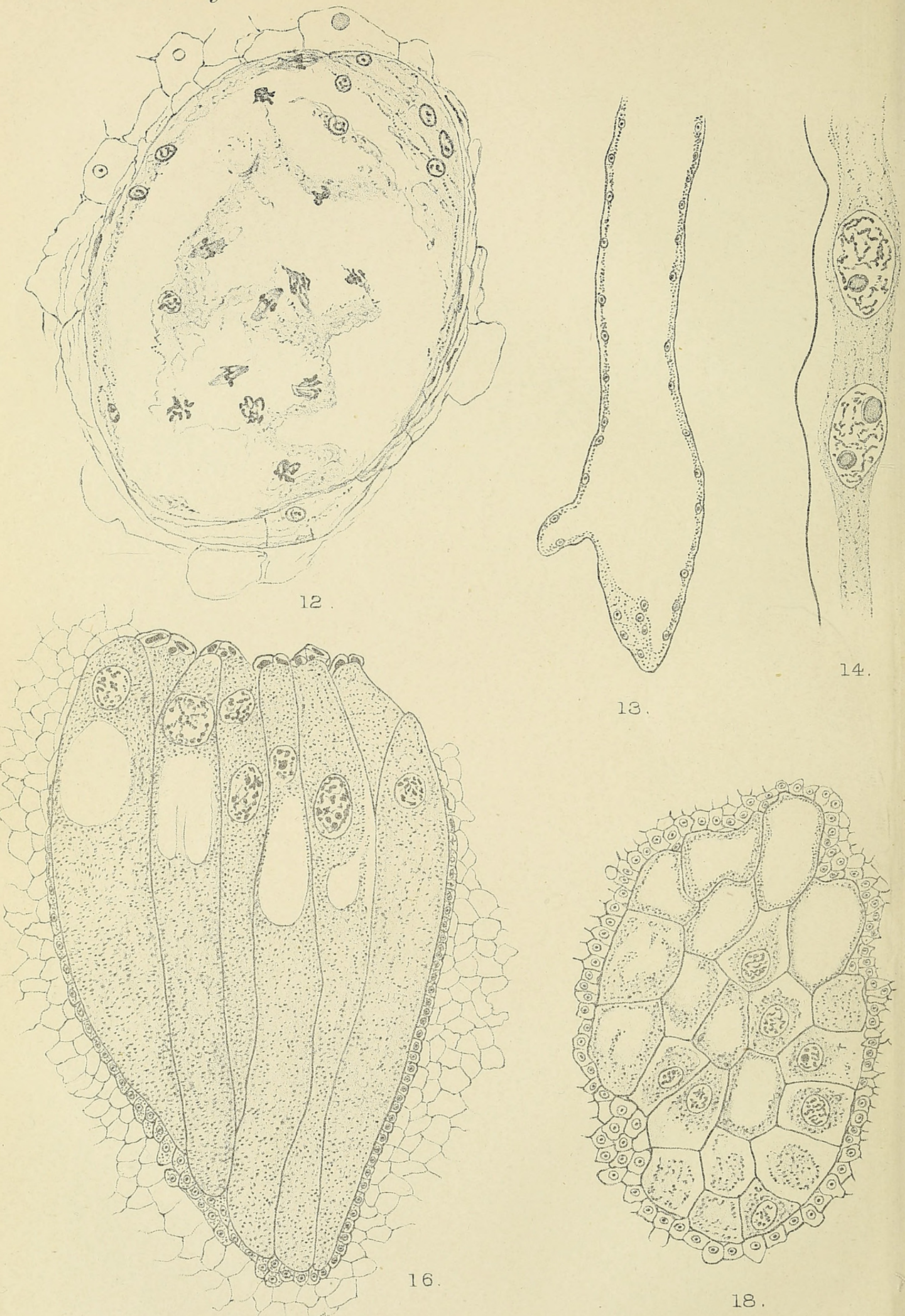

18. 


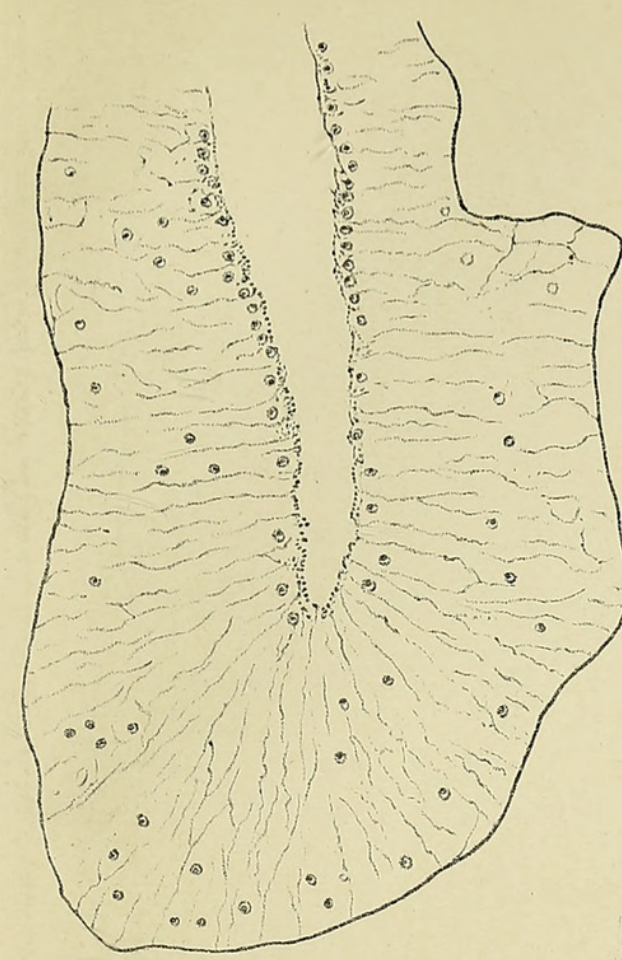

15.
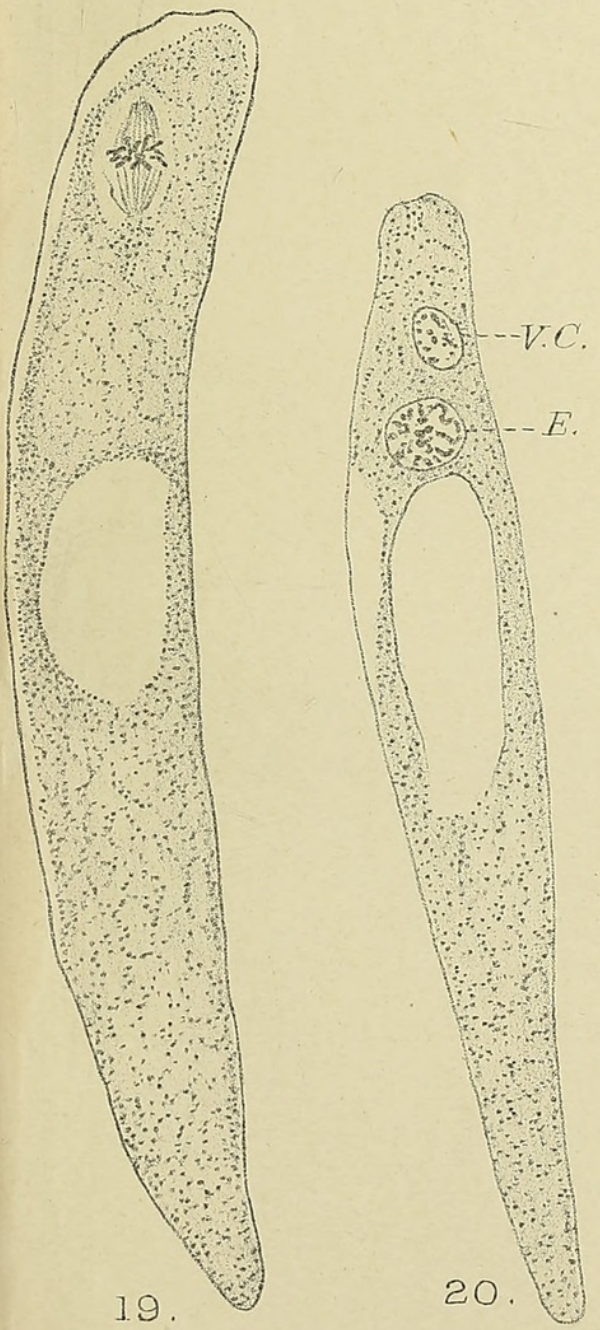

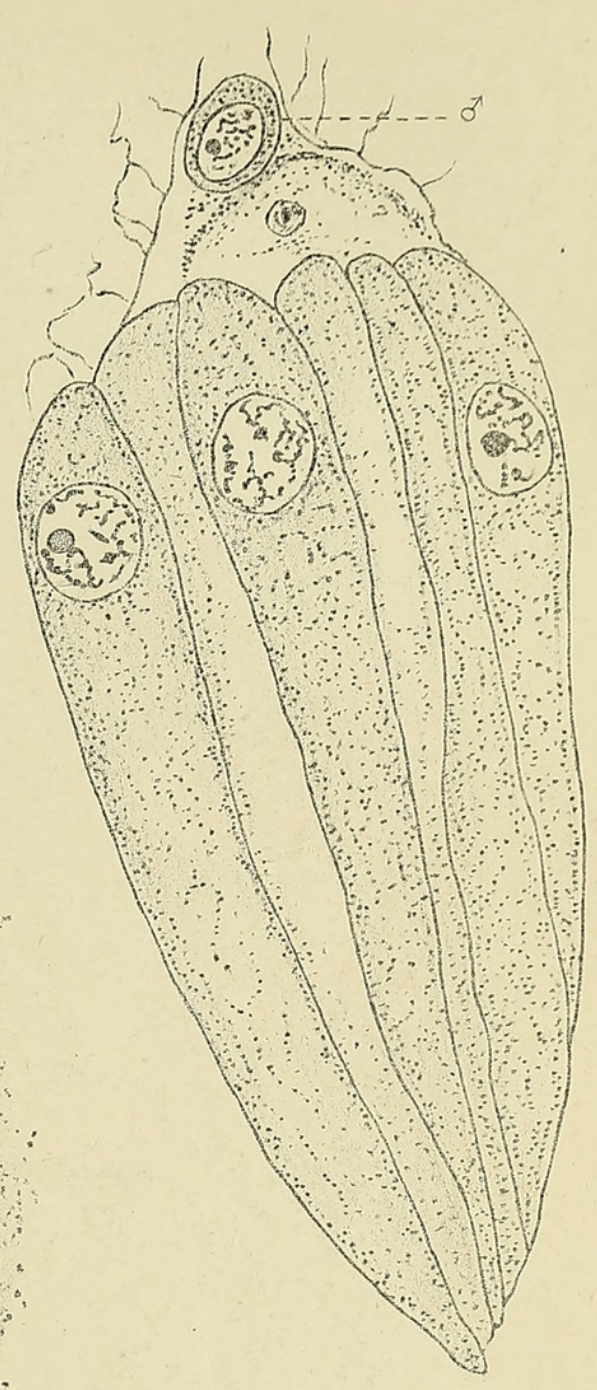

17.
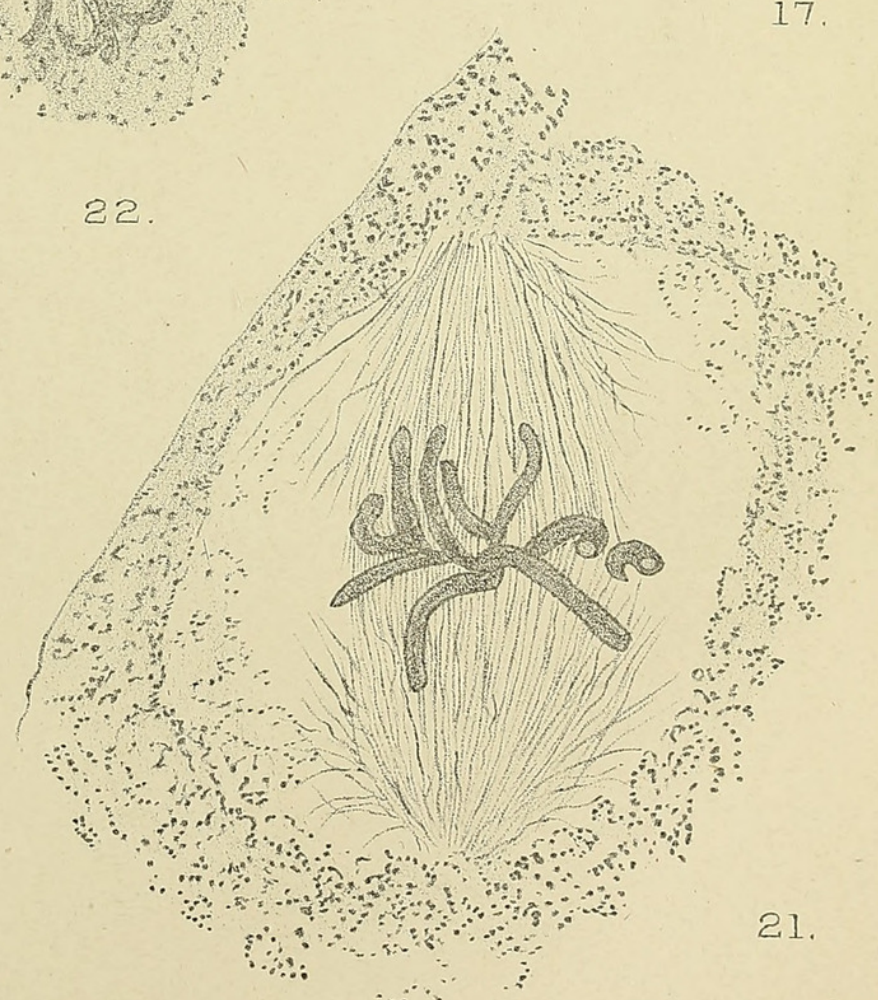

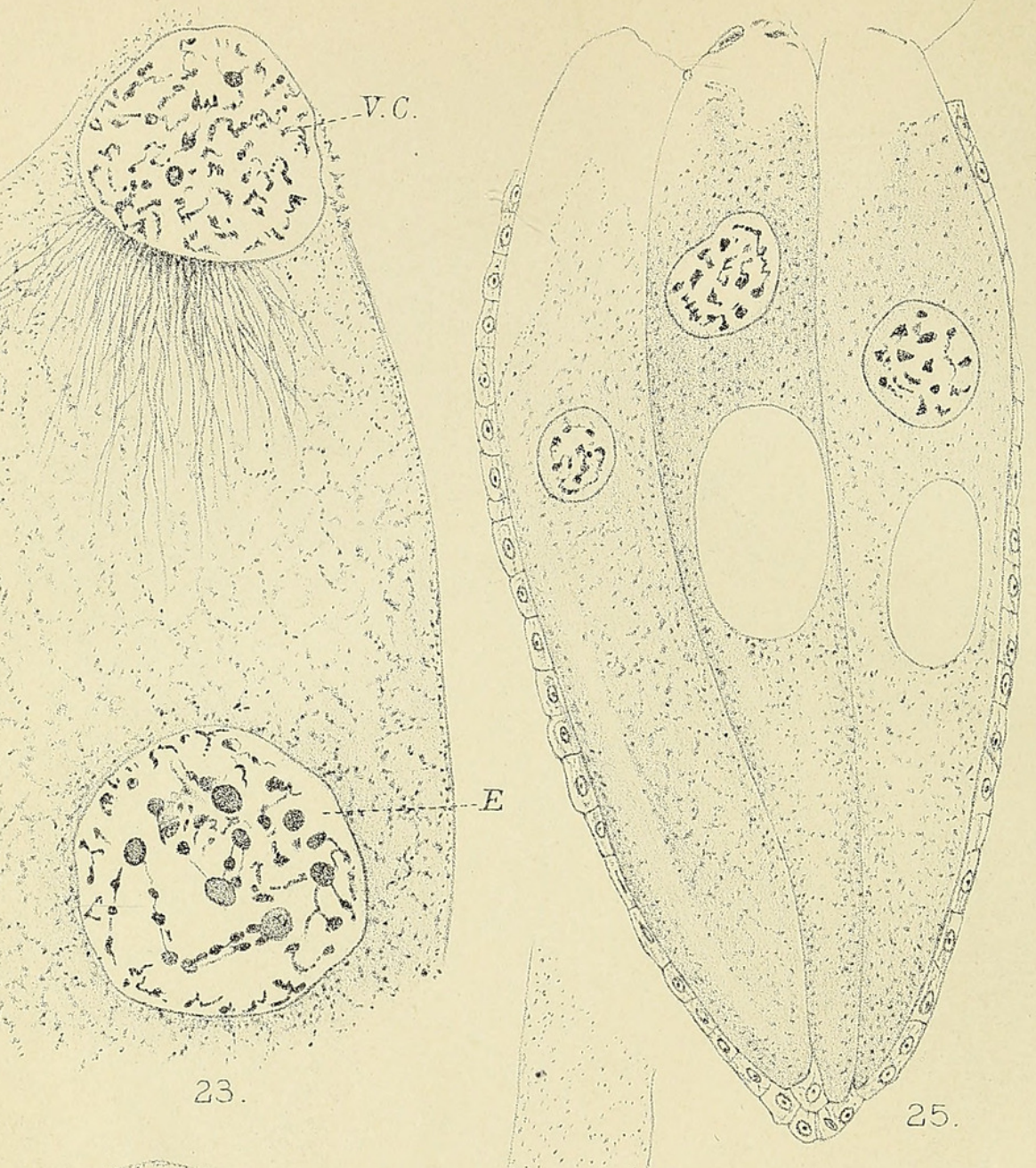

23
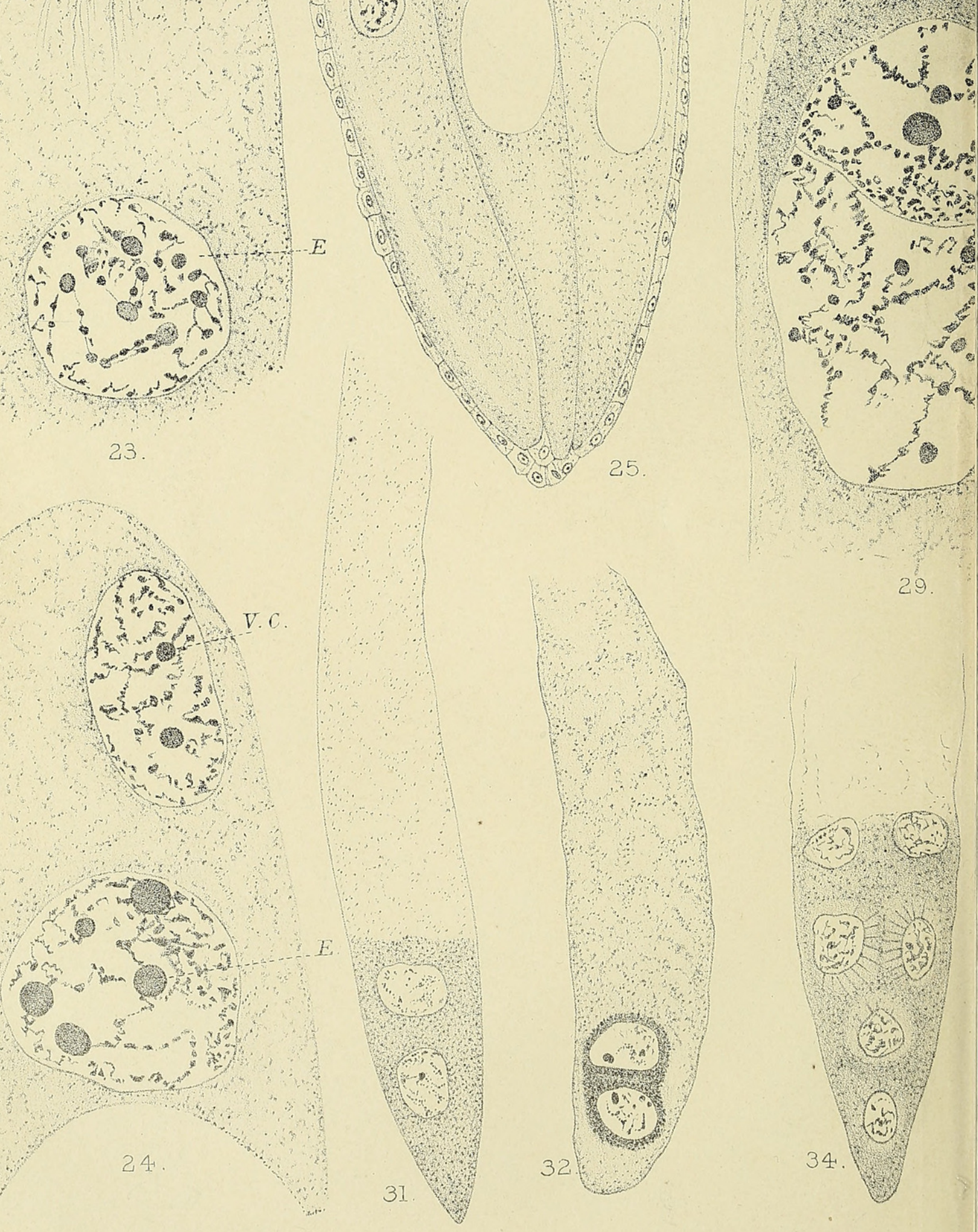

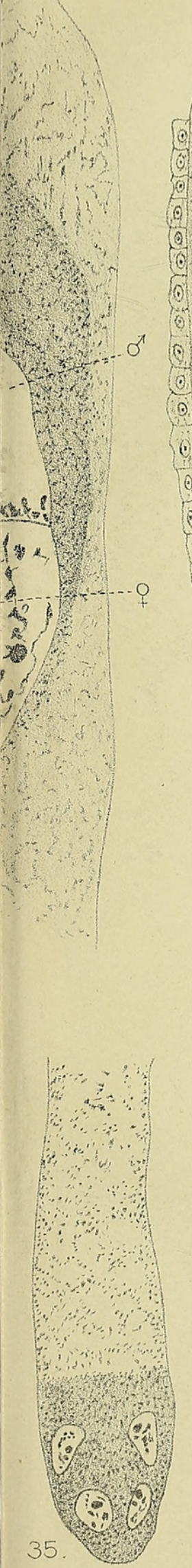
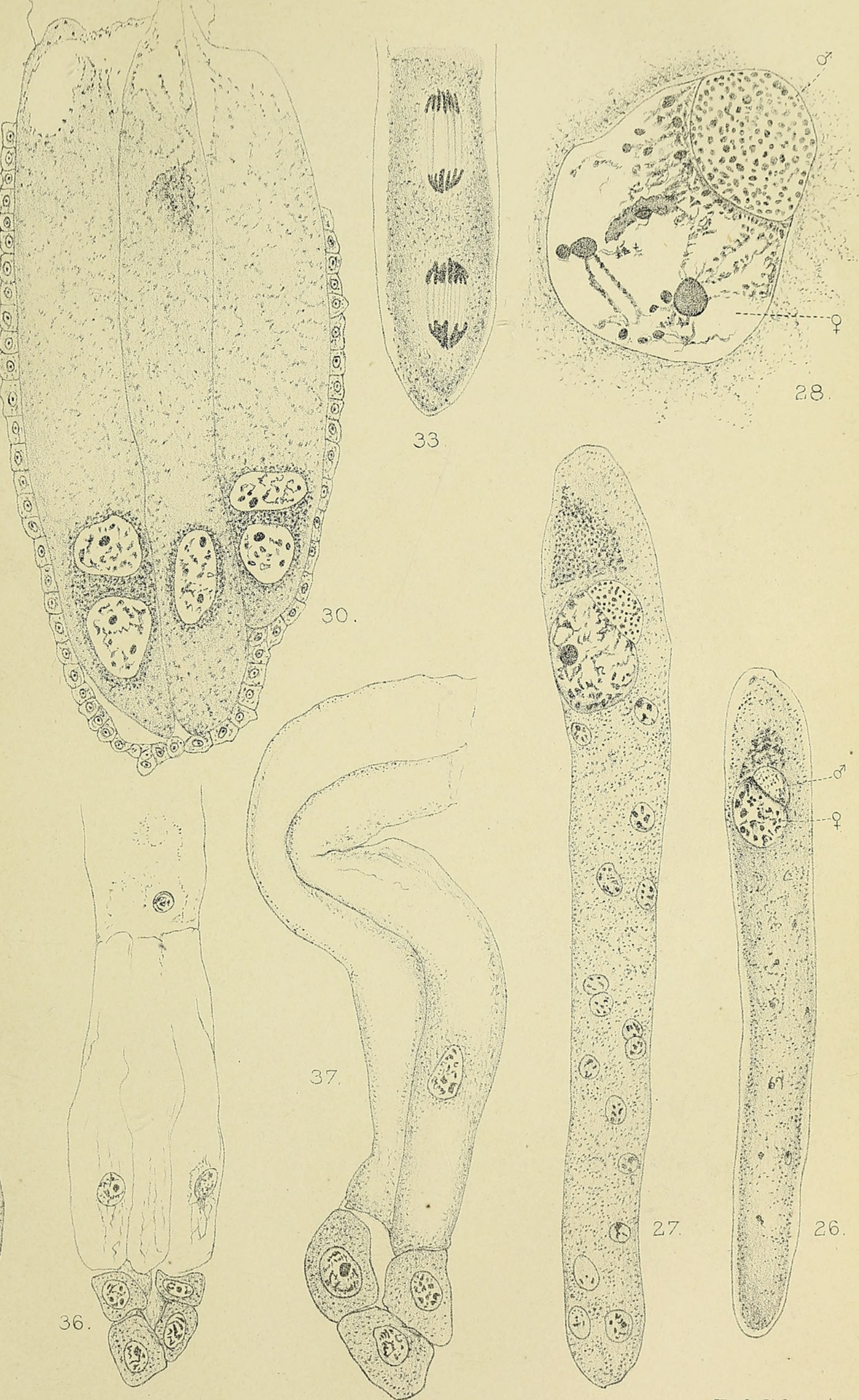

Huth.Iith et imp 

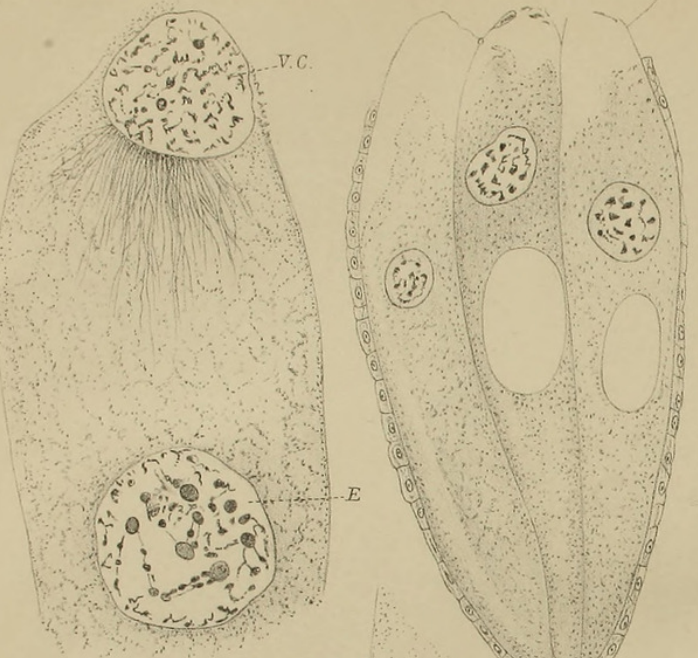

23.

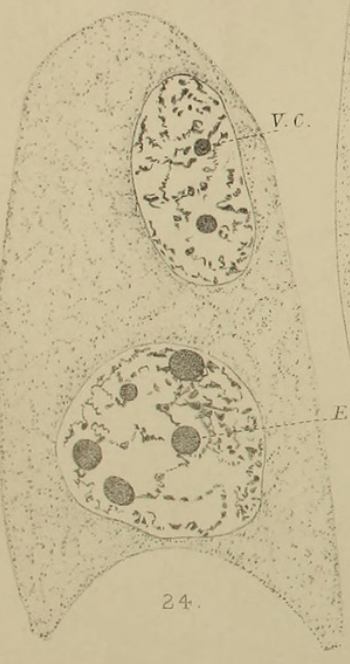

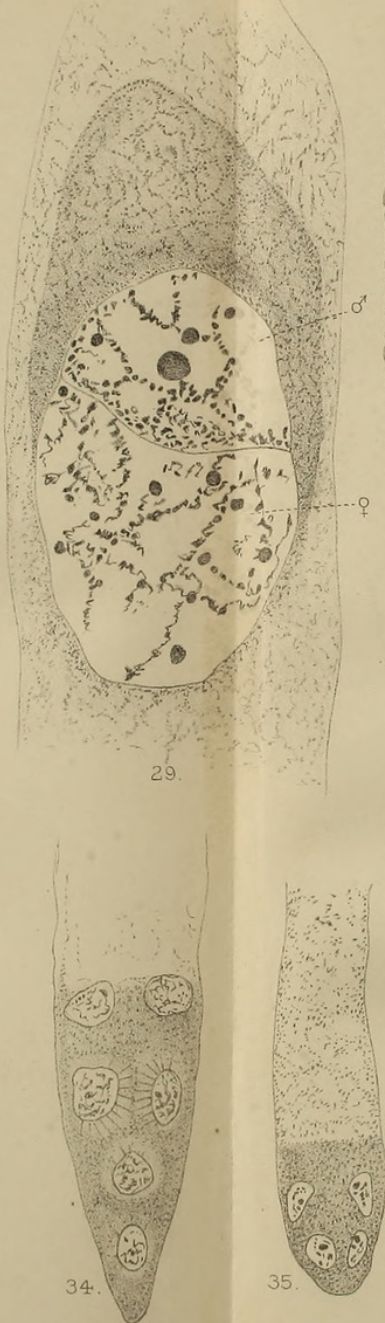

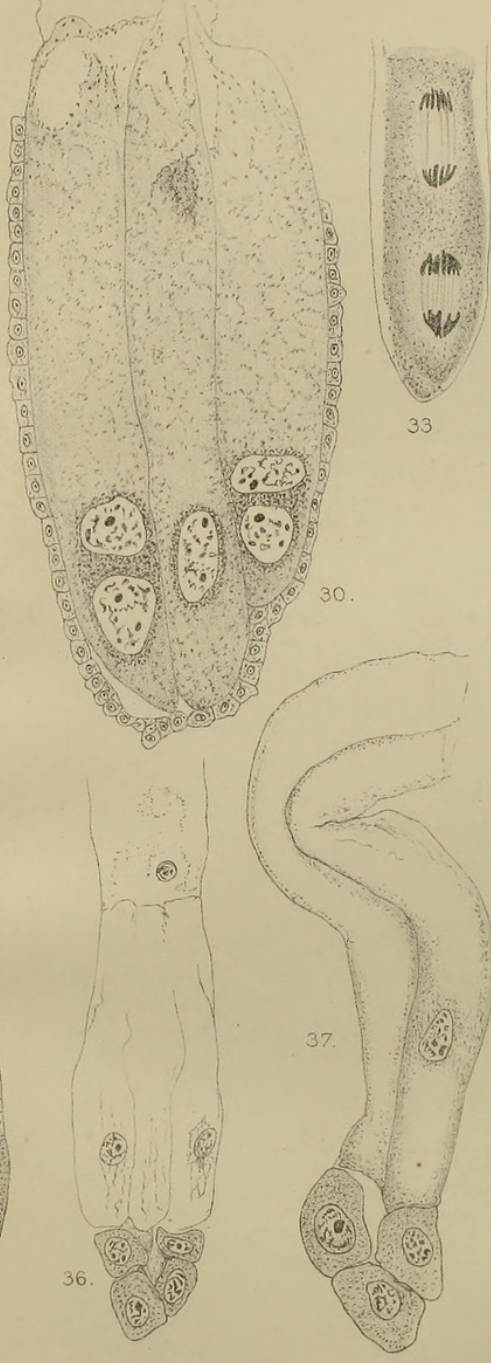

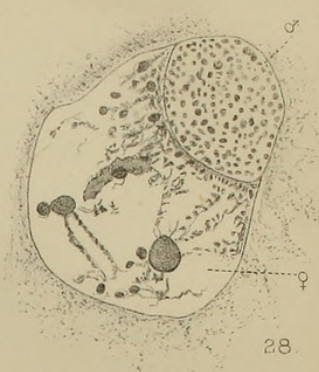

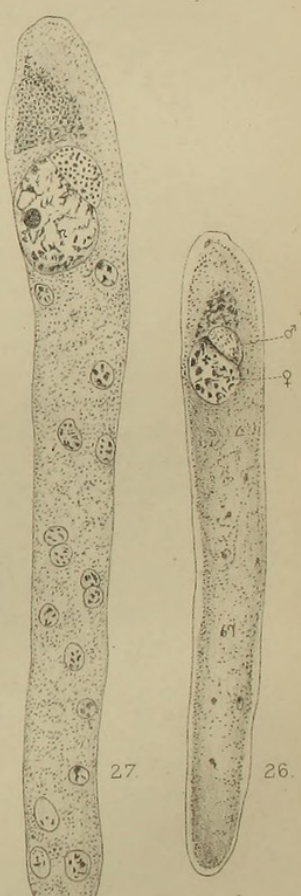

LAVSON. - CUPRESSINEAE. 


\section{$2 \mathrm{BHL}$ Biodiversity Heritage Library}

Lawson, Abercrombie Anstruther. 1907. "The gametophytes and embryo of the Cupressineae with special reference to Libocedrus decurrens." Annals of botany 21, 281-301. https://doi.org/10.1093/oxfordjournals.aob.a089134.

View This Item Online: https://www.biodiversitylibrary.org/item/235747

DOI: https://doi.org/10.1093/oxfordjournals.aob.a089134

Permalink: https://www.biodiversitylibrary.org/partpdf/318873

\section{Holding Institution}

Smithsonian Libraries

\section{Sponsored by}

Biodiversity Heritage Library

\section{Copyright \& Reuse}

Copyright Status: Not in copyright. The BHL knows of no copyright restrictions on this item.

This document was created from content at the Biodiversity Heritage Library, the world's largest open access digital library for biodiversity literature and archives. Visit BHL at https://www.biodiversitylibrary.org. 